\title{
Four-dimensional distribution of the 2010 Eyjafjallajökull volcanic cloud over Europe observed by EARLINET
}

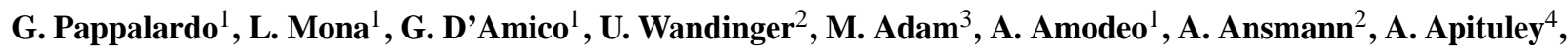
L. Alados Arboledas ${ }^{5}$, D. Balis ${ }^{6}$, A. Boselli ${ }^{1}$, J. A. Bravo-Aranda ${ }^{5}$, A. Chaikovsky ${ }^{7}$, A. Comeron ${ }^{8}$, J. Cuesta $^{9}, 10$, F. De Tomasi ${ }^{11}$, V. Freudenthaler ${ }^{12}$, M. Gausa ${ }^{13}$, E. Giannakaki ${ }^{6,14}$, H. Giehl ${ }^{15}$, A. Giunta ${ }^{1}$, I. Grigorov ${ }^{16}$, S. Groß ${ }^{12,17}$, M. Haeffelin ${ }^{18}$, A. Hiebsch ${ }^{2}$, M. Iarlori ${ }^{19}$, D. Lange ${ }^{8}$, H. Linné2 ${ }^{20}$, F. Madonna ${ }^{1}$, I. Mattis ${ }^{2,21}$, R.-E. Mamouri ${ }^{22}$, M. A. P. McAuliffe ${ }^{23}$, V. Mitev ${ }^{24}$, F. Molero ${ }^{25}$, F. Navas-Guzman ${ }^{5}$, D. Nicolae $^{26}$, A. Papayannis ${ }^{22}$, M. R. Perrone ${ }^{11}$, C. Pietras ${ }^{18}$, A. Pietruczuk ${ }^{27}$, G. Pisani ${ }^{28}$, J. Preißler ${ }^{29}$, M. Pujadas ${ }^{25}$, V. Rizi ${ }^{19}$, A. A. Ruth ${ }^{23}$, J. Schmidt ${ }^{2}$, F. Schnell ${ }^{12}$, P. Seifert ${ }^{2}$, I. Serikov ${ }^{20}$, M. Sicard ${ }^{8}$, V. Simeonov ${ }^{30}$, N. Spinelli ${ }^{28}$, K. Stebel ${ }^{31}$, M. Tesche ${ }^{2,32}$, T. Trickl ${ }^{15}$, X. Wang ${ }^{28}$, F. Wagner ${ }^{29}$, M. Wiegner ${ }^{12}$, and K. M. Wilson ${ }^{4}$

${ }^{1}$ Istituto di Metodologie per l'Analisi Ambientale CNR-IMAA, C.da S. Loja, Tito Scalo, Potenza 85050, Italy

${ }^{2}$ Leibniz-Institut für Troposphärenforschung, Leipzig, Germany

${ }^{3}$ EC Joint Research Centre, Ispra (VA), Italy

${ }^{4}$ KNMI - Royal Netherlands Meteorological Institute, The Bilt, the Netherlands

${ }^{5}$ Universidad de Granada, Granada, Spain

${ }^{6}$ Aristoteleio Panepistimio, Thessalonikis, Greece

${ }^{7}$ Institute of Physics, National Academy of Sciences, Minsk, Bjelarus

${ }^{8}$ Universitat Politècnica de Catalunya, Barcelona, Spain

${ }^{9}$ LATMOS, CNRS UMR8190, Université Pierre et Marie Curie, Paris, France

${ }^{10}$ LISA, CNRS UMR7583, Université Paris-Est Créteil and Université Paris-Diderot, Créteil, France

${ }^{11}$ Università del Salento, Department of Mathematics and Physics, Lecce, Italy

${ }^{12}$ Ludwig-Maximilians-Universität, Munich, Germany

${ }^{13}$ Andøya Rocket Range, Andenes, Norway

${ }^{14}$ Finnish Meteorological Institute, Kuopio Unit, Finland

${ }^{15}$ Karlsruher Institut für Technologie, Garmisch-Partenkirchen, Germany

${ }^{16}$ Institute of Electronics, Bulgarian Academy of Sciences, Sofia, Bulgaria

${ }^{17}$ Deutsches Zentrum für Luft- und Raumfahrt, Institut f. Physik d. Atmosphäre, Oberpfaffenhofen, Germany

${ }^{18}$ Université Pierre et Maris Curie-Institut Pierre Simon Laplace, Paris, France

${ }^{19}$ CETEMPS, Dipartimento di Scienze Fisiche e Chimiche, Università Degli Studi dell’ Aquila, Italy

${ }^{20}$ Max-Planck-Institut für Meteorologie, Hamburg, Germany

${ }^{21}$ Deutscher Wetterdienst, Meteorologisches Observatorium Hohenpeißenberg, Hohenpeißenberg, Germany

${ }^{22}$ National Technical University of Athens, Department of Physics, Athens, Greece

${ }^{23}$ Physics Department \& Environmental Research Institute, University College Cork, Cork, Ireland

${ }^{24}$ CSEM, Centre Suisse d'Electronique et de Microtechnique SA, Neuchâtel, Switzerland

${ }^{25}$ Centro de Investigaciones Energéticas, Medioambientales y Tecnológicas, Madrid, Spain

${ }^{26}$ National Institute of R\&D for Optoelectronics, Magurele-Bucharest, Romania

${ }^{27}$ Institute of Geophysics, Polish Academy of Sciences, Warsaw, Poland

${ }^{28}$ Consorzio Nazionale Interuniversitario per le Scienze Fisiche della Materia, Naples, Italy

${ }^{29}$ Universidade de Évora, Centro de Geofísica de Évora, Évora, Portugal

${ }^{30}$ Ecole Polytechnique Fédérale de Lausanne, Lausanne, Switzerland

${ }^{31}$ Norwegian Institute for Air Research (NILU), Kjeller, Norway

${ }^{32}$ Department of Applied Environmental Science (ITM), Stockholm University, Stockholm, Sweden

Correspondence to: G. Pappalardo (pappalardo@imaa.cnr.it)

Received: 26 October 2012 - Published in Atmos. Chem. Phys. Discuss.: 22 November 2012

Revised: 5 April 2013 - Accepted: 9 April 2013 - Published: 29 April 2013

Published by Copernicus Publications on behalf of the European Geosciences Union. 
Abstract. The eruption of the Icelandic volcano Eyjafjallajökull in April-May 2010 represents a "natural experiment" to study the impact of volcanic emissions on a continental scale. For the first time, quantitative data about the presence, altitude, and layering of the volcanic cloud, in conjunction with optical information, are available for most parts of Europe derived from the observations by the European Aerosol Research Lidar NETwork (EARLINET). Based on multi-wavelength Raman lidar systems, EARLINET is the only instrument worldwide that is able to provide dense time series of high-quality optical data to be used for aerosol typing and for the retrieval of particle microphysical properties as a function of altitude.

In this work we show the four-dimensional (4-D) distribution of the Eyjafjallajökull volcanic cloud in the troposphere over Europe as observed by EARLINET during the entire volcanic event (15 April-26 May 2010). All optical properties directly measured (backscatter, extinction, and particle linear depolarization ratio) are stored in the EARLINET database available at www.earlinet.org. A specific relational database providing the volcanic mask over Europe, realized ad hoc for this specific event, has been developed and is available on request at www.earlinet.org.

During the first days after the eruption, volcanic particles were detected over Central Europe within a wide range of altitudes, from the upper troposphere down to the local planetary boundary layer (PBL). After 19 April 2010, volcanic particles were detected over southern and south-eastern Europe. During the first half of May (5-15 May), material emitted by the Eyjafjallajökull volcano was detected over Spain and Portugal and then over the Mediterranean and the Balkans. The last observations of the event were recorded until 25 May in Central Europe and in the Eastern Mediterranean area.

The 4-D distribution of volcanic aerosol layering and optical properties on European scale reported here provides an unprecedented data set for evaluating satellite data and aerosol dispersion models for this kind of volcanic events.

\section{Introduction}

Aerosols originating from volcanic emissions have an impact on the climate (e.g., Hansen et al., 1997; Robock, 2000; Solomon et al., 2011): sulfate and ash particles from volcanic emissions reflect solar radiation, act as cloud condensation and ice nuclei, and modify the radiative properties and lifetime of clouds, and therefore influence the precipitation cycle. These volcanic particles can also have an impact on environmental conditions and can be very dangerous for air traffic.

Lidar (light detection and ranging) techniques represent a powerful method for monitoring the dispersion of a volcanic cloud in the atmosphere because of their profiling capabil- ity. In particular, lidar techniques provide geometrical properties (top, bottom, and thickness) for each volcanic layer, optical properties (extinction, backscatter, and optical depth), aerosol typing and in some cases also microphysical properties if advanced multi-wavelength Raman lidar systems are used.

The impact of particularly violent volcanic eruptions on the stratospheric aerosol load has been studied with lidar remote sensing since the early 1970s (e.g., Jäger, 2005; Deshler et al., 2006; Deshler, 2008). The most important eruptions during this period were those of El Chichon (Mexico, 1982) and Mt. Pinatubo (Philippines, 1991). After 1996 there was a ten-year period without appreciable volcanic activity, which ended by the end of 2006 when a series of several eruptions injected particles into the stratosphere that were recorded with lidar systems world-wide (Mattis et al., 2010; Kravitz et al., 2011; Sawamura et al., 2012; Trickl et al., 2012). Although many lidar observations are available for volcanic aerosol in the stratosphere, only a few are known for tropospheric events before 2010, such as those related to Etna volcanic eruptions in 2001 and 2002 (Pappalardo et al., 2004a; Villani et al., 2006; Wang et al., 2008).

Eyjafjallajökull $\left(63.63^{\circ} \mathrm{N}, 19.60^{\circ} \mathrm{W}, 1666 \mathrm{~m}\right.$ a.s.l. $)$ is one of the smallest glaciers in Iceland. After seismic activity recorded during December 2009, a first eruption started on 20 March 2010, between 22:30 and 23:30 UTC. After a brief stop, a new phase of the Eyjafjallajökull eruption started around midnight on 14 April, when meltwater penetrated to the central crater beneath the glacier. After a short hiatus in eruptive activity, a new set of craters opened up in the early morning of 14 April under the volcano's ice-covered central summit caldera. Meltwater started to emanate from the ice cap around 07:00 UTC on 14 April, and an eruption plume was observed in the early morning. The Eyjafjallajökull explosive eruptive phase started on 14 April 2010 lasted until 21 May 2010 (Langmann et al., 2012).

The ash-loaded eruption plume rose to more than $10 \mathrm{~km}$ height, deflected to the east by westerly winds. The height of the emitted plume was around $8 \mathrm{~km}$ until 16 April and decreased to a typical maximum height of $3-4 \mathrm{~km}$ in the following days (Arason et al., 2011). The plume rose up again to an altitude of 5-6 km in the period of 4-20 May (Langmann et al., 2012).

Depending on the wind direction, the eruption plume was transported toward different regions of continental Europe and toward the Atlantic Ocean at different altitudes. Even though this eruption was only moderate in intensity, it had a strong impact on air traffic. In order to prevent possible damages to aircraft engines, the airspace over large parts of Northern Europe was closed on 15 April when the first parts of the eruption plume reached continental Europe. Air traffic restrictions and partial closure of European airspace were not uniform during the eruption period and differed from region to region depending on the volcanic ash transport pattern and 
the (sparse) information on height and density of volcanic aerosol at the time.

The first characterization of the volcanic ash cloud was provided by Ansmann et al. (2010) relying on EARLINET lidar observations at Leipzig and Munich, Germany. EARLINET, the European Aerosol Research Lidar Network (Bösenberg et al., 2001), performed almost continuous measurements from 15 April 2010 in order to follow the evolution of the volcanic cloud over Europe.

During the event (15 April-26 May 2010), the volcanic cloud was transported to different regions of Europe at different altitudes and times and with a large variety in load. Volcanic particles were first observed in the UK, Ireland, the Netherlands, Germany, and France from very low altitudes up to the upper troposphere (e.g., Ansmann et al., 2011; Pappalardo et al., 2010a; Schumann et al., 2011; Hervo et al., 2012; Matthias et al., 2012). The volcanic cloud was then observed over Switzerland, Poland, and Norway (Pietruczuk et al., 2010; Schumann et al., 2011). The cloud reached Italy and Greece after 19 April (Mona et al., 2012; Papayannis et al., 2011). In May 2010, the volcanic cloud was transported over the Iberian Peninsula (Sicard et al., 2012; NavasGuzmán et al., 2013) and then moved towards the East, reaching Italy, Greece, and Turkey (Mona et al., 2012; Perrone et al., 2012; Papayannis et al., 2012). A series of publications covered the in-depth characterization of the ash cloud over different parts of Europe, combining measurements of lidars, sun photometers, and in situ probes. Schumann et al. (2011) reported on measurements on board the German research aircraft Falcon that covered several flights over Central Europe, Iceland, and the North Sea. Groß et al. (2011) demonstrated the potential of lidar-derived intensive aerosol properties to distinguish volcanic aerosol from other types. Further aircraft observations of the volcanic cloud including an on board lidar were performed over France (Chazette et al., 2012) and the United Kingdom (Marenco et al., 2011). Wiegner et al. (2012) demonstrated the benefit of lidar observations for the validation of the spatial distribution and mass concentration as calculated by a chemistry-transport model. The derivation of mass concentration as the most relevant property for air safety issues using data of advanced EARLINET-type lidars and sun photometers was covered in detail by Ansmann et al. (2011), Gasteiger et al. (2011), and Sicard et al. (2012). Despite the limited revisit time and field of view, also CALIOP, the backscatter lidar carried on the CALIPSO satellite, observed the volcanic cloud (Winker et al., 2012). Scientific literature for this event is related to specific cases studied in detail (e.g. Ansmann et al., 2010; Gasteiger et al., 2011; Schumann et al., 2011; Marenco et al., 2011, Marenco and Hogan, 2011; Newman et al., 2012; Turnbull et al., 2012) or specific regions (e.g. Flentje et al., 2010; Ansmann et al., 2011; Bukowiecki et al., 2011; Emeis et al., 2011; Groß et al., 2011; Schäfer et al., 2011; Chazette et al., 2012; Hervo et al., 2012; Mona et al., 2012; Papayannis et al., 2012; Sicard et al., 2012). A study presenting profiling observations for the whole volcanic event on a continental scale has not been published yet.

The main objective of this work is to summarize the spatial and temporal evolution of the volcanic cloud generated by the Eyjafjallajökull eruption for the entire Eyjafjallajökull volcanic event (15 April-26 May 2010) as observed by the coordinated ground-based lidar network EARLINET.

Volcanic particle layers have been identified for all the EARLINET stations using a specific backtrajectory-modelslidar observations integrated methodology for a volcanic aerosol masking (Mona et al., 2012).

EARLINET observations performed during the Eyjafjallajökull eruption event are described in Sect. 2. The volcanic aerosol masking is presented in Sect. 3, and results of the 4dimensional distribution of the volcanic cloud are discussed in Sect. 4. Finally a summary is given in Sect. 5.

\section{EARLINET and its observations during the volcanic event}

EARLINET, established in 2000, is the first coordinated aerosol lidar network whose key remit is the provision of a comprehensive, quantitative, and statistically significant database on the spatial and temporal aerosol distribution on a continental scale (Bösenberg, et al., 2001). At present, the network includes 27 stations distributed over Europe (see Table 1). More information about EARLINET can be found at www.earlinet.org.

Lidar observations within the network are performed on a regular schedule since May 2000, allowing for the collection of long-term data sets for climatological studies (Matthias et al., 2004a). In addition to the routine measurements, further observations are devoted to the monitoring of special events such as Saharan dust outbreaks (Ansmann et al., 2003; Mona et al., 2006; Papayannis et al., 2008; Guerrero-Rascado et al., 2009; Wiegner et al., 2011), forest fires (Müller et al., 2007; Amiridis et al., 2009), photochemical smog (Carnuth et al., 2002) mixed with biomass burning particles (Mamouri et al., 2012), and volcanic eruptions (Pappalardo et al., 2004a; Wang et al., 2008; Mattis et al., 2010).

Data quality has been assured by inter-comparisons at instrument level using the available transportable systems (Matthias et al., 2004b; Freudenthaler et al., 2010). Data quality assurance also includes the inter-comparison of group-specific retrieval algorithms for both backscatter and Raman lidar data (Böckmann et al., 2004; Pappalardo et al., 2004b). Based on well-defined common standards, the routinely performed quality-assurance exercises of lidar instruments and algorithms ensure that the data products provided by the individual stations are homogenous and continuously of highest possible reliability. Efforts to guarantee and improve the quality of data derived from observations in EARLINET are continuous (Freudenthaler et al., 2010). 
Table 1. Locations of EARLINET lidar stations, corresponding ID code, altitude, and geographical coordinates.

\begin{tabular}{|c|c|c|c|c|}
\hline Site & ID & Altitude a.s.l. (m) & Lat. (N) & Long. (E) \\
\hline Andenes, Norway & an & 380 & 69.28 & 16.01 \\
\hline Athens, Greece & at & 200 & 37.96 & 23.78 \\
\hline Barcelona, Spain & ba & 115 & 41.39 & 2.11 \\
\hline Belsk, Poland & be & 180 & 51.84 & 20.79 \\
\hline Bucharest-Magurele, Romania & bu & 93 & 44.45 & 26.03 \\
\hline Cabauw, the Netherlands & $\mathrm{ca}$ & 1 & 51.97 & 4.93 \\
\hline Cork, Ireland & co & 75 & 51.89 & -8.49 \\
\hline Evora, Portugal & ev & 293 & 38.57 & -7.91 \\
\hline Garmisch-Partenkirchen, Germany & gp & 730 & 47.48 & 11.06 \\
\hline Granada, Spain & $\mathrm{gr}$ & 680 & 37.16 & -3.61 \\
\hline Hamburg, Germany & hh & 25 & 53.57 & 9.97 \\
\hline Ispra, Italy & is & 209 & 45.82 & 8.63 \\
\hline L'Aquila, Italy & la & 683 & 42.38 & 13.32 \\
\hline Lecce, Italy & lc & 30 & 40.30 & 18.10 \\
\hline Leipzig, Germany & le & 100 & 51.35 & 12.44 \\
\hline Linköping, Sweden & $1 \mathrm{k}$ & 80 & 58.39 & 15.57 \\
\hline Madrid, Spain & $\mathrm{ma}$ & 669 & 40.45 & -3.73 \\
\hline Maisach, Germany & $\mathrm{ms}$ & 515 & 48.21 & 11.26 \\
\hline Minsk, Belarus & $\mathrm{mi}$ & 200 & 53.92 & 27.60 \\
\hline Munich, Germany & $\mathrm{mu}$ & 539 & 48.15 & 11.57 \\
\hline Naples, Italy & na & 118 & 40.84 & 14.18 \\
\hline Neuchâtel, Switzerland & ne & 487 & 47.00 & 6.96 \\
\hline Palaiseau, France & $\mathrm{pl}$ & 162 & 48.70 & 2.20 \\
\hline Payerne, Switzerland & py & 456 & 46.81 & 6.94 \\
\hline Potenza-Tito Scalo, Italy & po & 760 & 40.60 & 15.72 \\
\hline Sofia, Bulgaria & sf & 550 & 42.67 & 23.33 \\
\hline Thessaloniki, Greece & th & 60 & 40.63 & 22.95 \\
\hline
\end{tabular}

All measured profiles are stored in a standardized data format in a centralized database which allows for easy access to the complete data set for further scientific studies. Presently, the EARLINET database represents the largest collection of ground-based data of the vertical aerosol distribution on a continental scale.

For the occurrence of special atmospheric events an alerting system has been implemented in EARLINET. In the case of the volcanic eruption of Eyjafjallajökull, an alert was sent to the whole network on 15 April 2010. The alert was based on information from different sources: (i) the Icelandic Meteorological Office Bulletin for the daily status of the volcanic event, (ii) the ash dispersion models provided by the volcanic ash advisory center (VAAC, http://www.metoffice. gov.uk/aviation/vaac/vaacuk_vag.html), (iii) the European air pollution dispersion (EURAD) model (http://www.eurad. uni-koeln.de/index_e.html), and (iv) available satellite data (as those provided by MODIS, SEVIRI, OMI, CALIPSO).

On 15 April the eruption plume reached continental Europe, causing closure of the airspace over large parts of Northern Europe. On the same day at 10:00 UTC an alert from CNR-IMAA, Potenza, was sent to all EARLINET stations informing them about a large amount of ash being transported towards the northwest of Europe. Almost all EAR-
LINET stations promptly started continuous measurements, whenever weather conditions allowed it.

Despite the fact that EARLINET stations are not truly operational, the lidar systems were run almost continuously, weather permitting, coordinated by daily alerts. More than $5000 \mathrm{~h}$ of measurements were performed day and night during the period 15 April-26 May 2010. Thus, the evolution of the volcanic cloud was monitored, providing, for the first time, a four-dimensional distribution of the volcanic cloud over Europe for the entire event. Even though the EARLINET observations were initially driven by scientific interest, it became obvious after a few days that the information obtained from the coordinated effort of the network would be very useful for European aviation authorities. A page with the quicklook data of the lidar range-corrected signals was made available on the EARLINET website in order to provide near-real-time qualitative information about the presence and altitudes of the volcanic cloud over Europe. The quicklooks were accompanied with a measurement report (updated daily) to explain the significance of the data at the time. Direct links with the World Meteorological Organization (WMO) and national agencies responsible for the flight zone safety were established. 
A first volcanic layer was observed at an altitude of ca. $3 \mathrm{~km}$ and up to $6 \mathrm{~km}$ over Hamburg in the early morning of 16 April. On the morning of 16 April, the major ash plume reached Central Europe (Germany and France) at 5$6 \mathrm{~km}$ a.s.l. and Belarus at ca. $4 \mathrm{~km}$ a.s.l. The volcanic cloud crossed Central and Eastern Europe on 16 and 17 April. Most EARLINET stations discovered a distinct feature at that time. The layer appeared first at 5-8 km a.s.l. and then decreased with time. Finally, volcanic aerosol was mixed into the local planetary boundary layer (PBL). After 17 April the volcanic plume was dispersed towards Western and Eastern Europe. The transport to the south was almost completely blocked by the Alps until 19 April when a redistribution of aged volcanic aerosol from west to east and from north to south occurred. On 20 April Italian EARLINET stations observed a clear signature of the plume for the first time. Afterwards, the plume was further dispersed across Europe and reached Greece on 21 April.

The volcanic plume persisted over Central Europe for the whole period of 15-26 April, even though with different aerosol load. Only small amounts of material were emitted by Eyjafjallajökull between 19 April and 3 May (see, e.g., Fig. 2 in Schumann et al., 2011). However, new significant eruptions occurred from 4-9 May and 14-19 May. The first of these phases mainly influenced Western Europe, from Great Britain to the Iberian Peninsula. EARLINET stations in Spain and Portugal reported the arrival of the first volcanic layers on 5 May (Sicard et al., 2012; Navas-Guzmán et al., 2013). On 16 May, a distinct ash plume travelled over Great Britain toward Central Europe again and reached the Central European EARLINET stations in the Netherlands and Germany in the night of 16-17 May (see, e.g., Fig. 14, 15, and 18 in Schumann et al., 2011). Volcanic layers were observed in Central Europe and in the Central and Eastern Mediterranean area on 18-22 May. Last observations of the event were recorded over Central Europe by 25 May.

\section{Volcanic aerosol mask}

A volcanic aerosol mask has been generated based on all EARLINET observations performed during the Eyjafjallajökull eruption (15 April-26 May 2010). The methodology for obtaining the mask is specific to this kind of event and was applied to the whole network. The approach is based on aerosol layer identification using only aerosol backscatter coefficients at one wavelength, so that daytime measurements could be included in the study and potential observational limitations of some stations were eliminated. For each station, the aerosol backscatter coefficient at the longest available wavelength in the 355-532-1064 nm range was used for the layering, thereby taking advantage of the better sensitivity to the aerosol structure at longer wavelengths. For aerosol typing, backward trajectory analyses and model outputs were used together with the multi-wavelength Raman li- dar measurements performed within the network during this event. The aerosol mask methodology provides snapshots of distinguishable aerosol type distributions over Europe with one hour temporal and high vertical resolution and unprecedented sensitivity to aerosol presence.

The mask was generated with a temporal resolution of $1 \mathrm{~h}$ in order to be able to compare the dataset directly with results from models (e.g., ECMWF) which typically provide data with a one-hour time resolution. The volcanic mask is provided with the best possible effective vertical resolution, as determined individually by each group within EARLINET, typically between 60 and $180 \mathrm{~m}$. Only backscatter data with a relative statistical error lower than $50 \%$ are considered in order to gain a reliable aerosol mask. The aerosol mask methodology is described in detail by Mona et al. (2012). The most relevant points are therefore only summarized here in brief.

The first step is the layer identification through the first derivative of the particle backscatter profiles. Tests performed on several EARLINET station data identified $30 \%$ as a reasonable statistical error limit for the application of the derivative method. At altitudes where the derivative method is not applicable, because the signal-to-noise ratio is too low, layers are identified as those regions where the scattering ratio (i.e. the total-to-molecular backscatter ratio) is higher than a pre-defined threshold chosen as the value for typical aerosol background conditions plus $15 \%$.

The second step in the procedure is to perform a rigorous cloud screening on the data and to assign an aerosol type to each identified layer. Cloud screening is performed manually by each station (low clouds) and in a centralized way (cirrus clouds). In particular, cirrus clouds are identified on the basis of cirrus high particle depolarization ratio, neutral wavelength dependence and temporal evolution. Backward trajectory analyses and model outputs are used to investigate the origin and nature of the identified aerosol layers. In particular, ten-day HYSPLIT backtrajectory analysis provided by NOAA (Draxler and Rolph, 2012; Rolph, 2012) is used, because the arrival altitudes and times could be chosen in a flexible way, which makes it very useful for a study on aerosol typing based on lidar data with high vertical and temporal resolution. In addition, German Meteorological Service (DWD), FLEXTRA (Stohl et al., 1995; Stohl, 1998), and NASA/Goddard (Schoeberl and Newman, 1995) backtrajectory analyses are used to check further the validity of the aerosol source identification. In particular, fourday backward DWD trajectories for two arrival times per day and for six arrival pressure levels between 200 and $975 \mathrm{hPa}$, as well as four-day backward FLEXTRA trajectories arriving at altitudes of 1500, 3000, and $5000 \mathrm{~m}$ every six hours are available for each EARLINET site. For EARLINET stations that are also AERONET sites, the backtrajectory analysis developed by the Atmospheric Chemistry and Dynamics Branch of NASA/Goddard are available at 00:00 UTC and 
12:00 UTC and were used for eight height levels between $950 \mathrm{hPa}$ and $200 \mathrm{hPa}$.

Once the particle path is identified through backtrajectory analysis, the type of the aerosol is investigated using model output and the support of the multi-wavelength Raman lidar measurements performed within the network. The Eyjafjallajökull volcanic activity and emission heights are also taken into account by using the reports provided by the Iceland Meteorological Office, VAAC, and dedicated studies (e.g. Langmann et al., 2012).

Within EARLINET, it has been shown that a careful analysis based on lidar observations, air-mass backtrajectories and modeling tools allows for a detailed classification of the observed aerosols (e.g. Mona et al., 2006; Muller et al., 2009; Villani et al., 2006; Pappalardo et al., 2010b). The methodology described above has been manually applied to all the layers identified. In most of the cases reported in this paper, the origin and type of the observed particles are clearly defined through the backtrajectories-models combined approach. Particular attention was needed in cases of transition between different atmospheric conditions because of the high instability of the backtrajectory analysis in the transient regimes. For these cases, advanced lidar observational capability and climatological analysis available at the observational site could permit the aerosol typing. An example of the aerosol typing for this condition is reported in detail in Mona et al. (2012). Situations not clearly identified with this kind of approach still remain and are reported as "unknown" aerosol in the masking.

Many types of aerosol may have been present over Europe during the whole eruptive period. Specific models and satellite observations are used in order to check the occurrences of other specific aerosol-related events along the identified aerosol paths. The potential presence of Saharan dust for instance is checked using the Dust REgional Atmospheric Model (DREAM) forecasts in terms of maps of the dust loading and dust concentration profiles at each EARLINET site, both available every six hours (http://www.bsc.es/projects/ earthscience/BSC-DREAM). The results of the ATSR World Fire Atlas (available at http://due.esrin.esa.int/wfa/) are used for identifying the presence of forest fire episodes. Cases with backtrajectories that are locally confined and without the presence of any specific source resulted in aerosol being classified as continental. For all the other cases with uncertain situations, aerosol is classified as "unknown". All possible mixes among these types of aerosol are also taken into account.

As far as volcanic aerosol is concerned, it should be noted that aerosol layers identified through this approach could consist of different ash and sulfate mixing ratios for different sites. Moreover, the observed particles of volcanic origin may be affected by modification processes and mixing with other air masses during transport. Aerosol layers, for which other aerosol sources besides the Eyjafjallajökull volcano can be identified, are classified as mixed aerosols.
The particle layer identification and typing is performed for each station on individual backscatter profiles. A consistency check is carried out on the temporal evolution of the resulting layering for each station. A further check is performed by taking advantage of the geographical distribution of EARLINET stations. In particular, stations located at relatively short distances (below $500 \mathrm{~km}$ ) from each other can be considered representative for a specific region, giving us the opportunity to also study local phenomena. When a doubtful atmospheric scenario is observed in a specific region, multiwavelength Raman lidar data from at least one close station, including lidar ratio, Ångström exponent, and particle linear depolarization ratio, are used as additional information supporting aerosol typing.

Four interesting examples of the overall event in terms of aerosol content at different locations and different phases of the volcanic cloud transport over Europe have been selected to better illustrate the methodology (see Figs. 1-4). Each of these is considered as a representative example (EX) for other aerosol occurrence and transport scenarios during the event: (EX1) almost direct transport towards Central Europe during the first phase of the eruption; (EX2) co-presence of dust and volcanic aerosol over France and other Mediterranean countries during the first phase of the eruption; (EX3) almost direct transport over the Iberian Peninsula at the beginning of May; (EX4) transport towards Central Europe at the end of May.

For each example, the aerosol mask is reported, providing in particular the following information:

1. Minimum and maximum altitudes covered in measurements. These can vary for each site depending on the corresponding lidar instrument performances and atmospheric conditions.

2. PBL height (as derived directly by the lidar signals) (Steyn et al., 1999).

3. Volcanic aerosol layers are reported in shades of grey. Different shades of grey refer to different aerosol backscatter values $\left(\beta_{\lambda}\right)$ [black: $\beta_{532}>1 \times 10^{-6} \mathrm{~m}^{-1}$ $\mathrm{sr}^{-1}$; grey: $1 \times 10^{-7}<\beta_{532}<1 \times 10^{-6} \mathrm{~m}^{-1} \mathrm{sr}^{-1}$; light grey: $\beta_{532}<1 \times 10^{-7} \mathrm{~m}^{-1} \mathrm{sr}^{-1}$; black: $\beta_{1064}>5 \times$ $10^{-7} \mathrm{~m}^{-1} \mathrm{sr}^{-1}$; grey: $5 \times 10^{-8}<\beta_{1064}<5 \times 10^{-7}$ $\mathrm{m}^{-1} \mathrm{sr}^{-1}$; light grey: $\beta_{1064}<5 \times 10^{-8} \mathrm{~m}^{-1} \mathrm{sr}^{-1}$ ]. No distinction between ash particles and smaller non-ash particles (mainly sulfate aerosol) of volcanic origin is made. The grey layers contain both of these components of aerosol, originating from the volcanic eruption and then eventually being subject to modifications that occur during the transport across the European continent.

4. Aerosol types: aerosol in the PBL (mainly local) is reported in yellow; continental aerosol in dark yellow, forest fires in light green; desert dust in orange; cloud/cirrus in cyan; volcanic mixing cases are shown in 


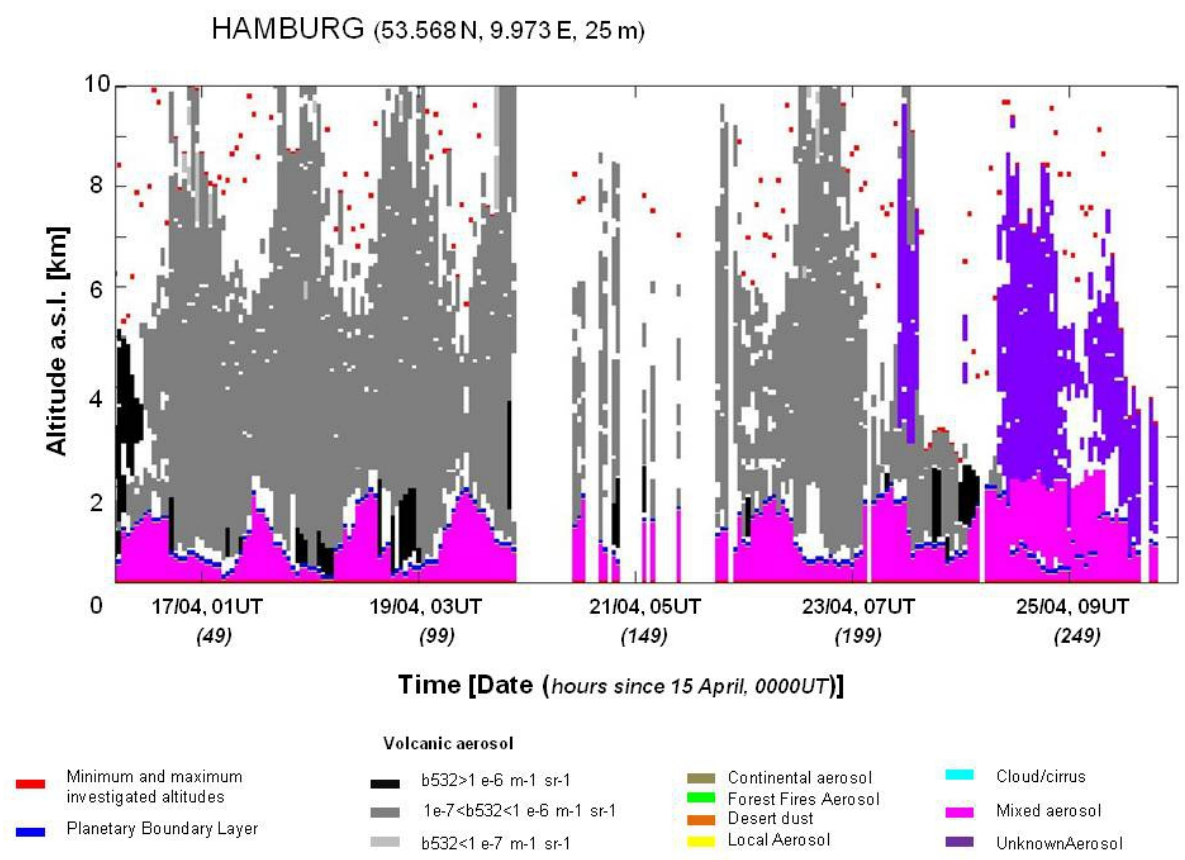

Fig. 1. Aerosol mask for the Hamburg EARLINET site in the 15-25 April 2010 period.

magenta. If the identification of the origin of particles in a layer was not possible, the corresponding aerosol was classified as unknown (purple).

\subsection{EX1}

The first example refers to the lidar observations performed at the EARLINET station in Hamburg, Germany, in the period 16-25 April 2010, i.e. during the initial phase of the volcanic event. The corresponding aerosol mask is shown in Fig. 1, where volcanic particles are represented in different shades of grey depending on the corresponding aerosol load. All other aerosol types, also mixed ones, are represented by different colours. The peak backscatter coefficients above Hamburg on 16 April are the highest found for the entire plume (see further below). Figure 1 clearly shows that volcanic particles were typically observed over the entire altitude range sounded by the lidar instrument. In particular, the intrusion of volcanic particles into the PBL appears to be very common for this station during this period. These situations are identified, in the whole study, on the basis of the temporal evolution of the layers and modification of aerosol optical properties in the PBL region, in particular of particle linear depolarization ratio and other intensive properties. Direct injection of volcanic particles from Iceland into the PBL, as well as transport of volcanic particles at higher altitudes (e.g., see data around 09:00 UTC on 23 April) was observed. During the night of 24-25 April, when air masses reaching Hamburg in the free troposphere arrived from over the Atlantic Ocean and the United States, it was not possible to identify a specific source of the observed aerosol, which is therefore labelled as unknown. No layers are reported in the mask for some times since the aerosol backscatter retrieval was not possible due to the presence of low clouds. The apparent temporal behaviour of the top altitude of the volcanic layer is exclusively related to an instrumental effect of the differences between daytime and nighttime signal-to-noise ratio conditions. During nighttime, the statistical error of the aerosol backscatter coefficient is lower than for data taken during daytime for a given altitude. This means that because of the pre-defined threshold for the statistical error $(50 \%)$, the layer identification algorithm operates as expected only for a lower altitude range during daytime compared to nighttime.

\subsection{EX2}

Figure 2 shows the aerosol mask for Palaiseau, France, for the period 23-24 April 2010. This is a very interesting period of the eruption event, where Saharan dust above $4 \mathrm{~km}$ and a layer of volcanic particles beneath it was observed. Aerosol typing in situations with different long-range transported aerosols is really challenging. In such cases advanced lidar observational capability and climatological analysis available at EARLINET sites could permit the aerosol typing. In particular, intensive properties and their temporal evolution are used here for discriminating different aerosol types such as dust and volcanic particles. A detailed example of aerosol typing for mixing situations is described in Mona et al. (2012). 


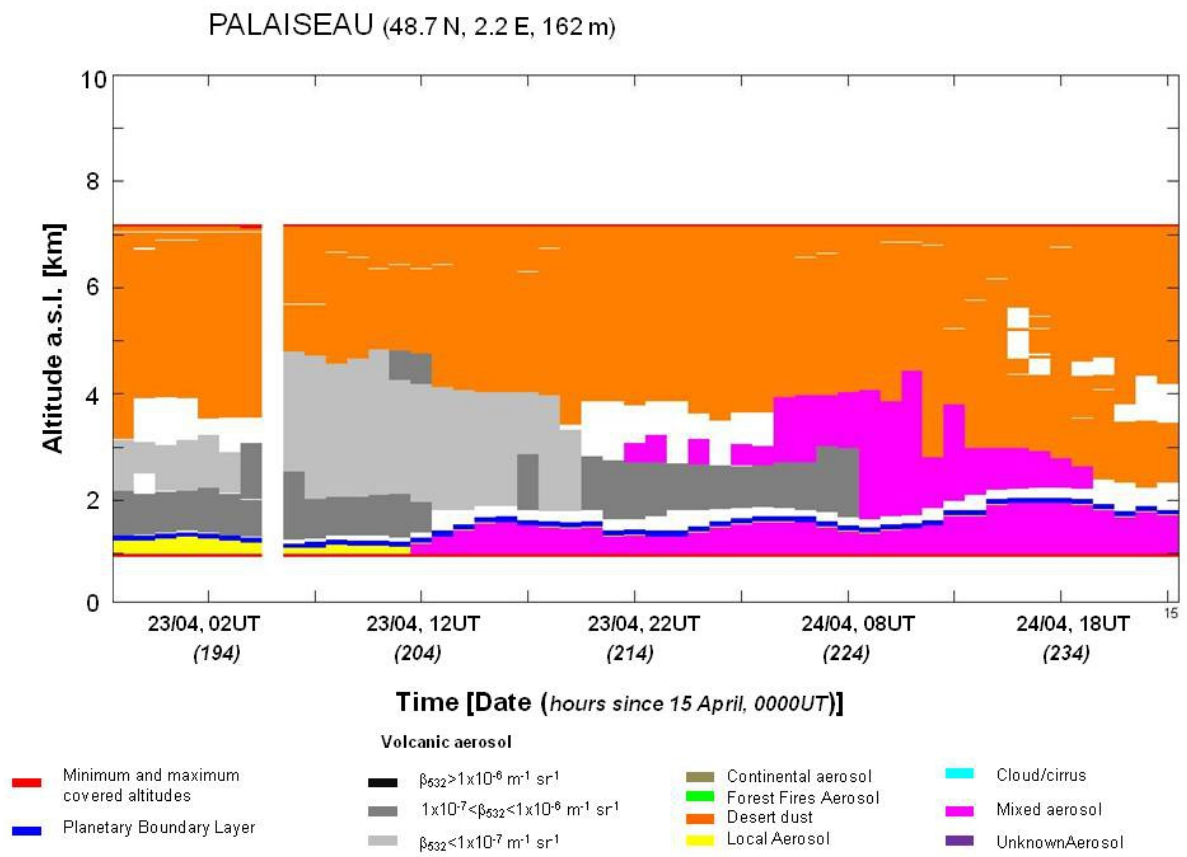

Fig. 2. Aerosol mask for the Palaiseau EARLINET site in the 23-24 April 2010 period.

Intrusion into the PBL was observed on 23 April starting at 11:00 UTC when the top altitude of the PBL rose while volcanic particles entered into the PBL. A mixed aerosol layer consisting of volcanic particles and Saharan dust was then observed on the evening of 23 April when the Saharan dust layer started to decrease in altitude, merging with the volcanic aerosol layer.

\subsection{EX3}

During most of the volcanic eruption period, the Iberian Peninsula was not affected by the presence of the volcanic cloud. The only exception was a ten-day period in May during which the wind transported volcanic particles directly toward Spain and Portugal. Figure 3 shows the volcanic aerosol mask over Granada, Spain, for the period 5-7 May 2010. This example shows a situation where volcanic particles were observed almost over the entire altitude range covered by the lidar instrument and intrusion into the PBL was also observed. Mixing of volcanic particles with local and dust particles was observed for the whole period up to an altitude of ca. $3 \mathrm{~km}$. Above $3 \mathrm{~km}$, the particle linear depolarization ratio was measured to be around $7 \%$. The values of $4-5 \%$ for the lower layer suggest the mixing of volcanic particles with other particles (Navas-Guzmán et al., 2013; Sicard et al., 2012).

\subsection{EX4}

In the final part of the 2010 Eyjafjallajökull eruption period, the volcanic cloud was mainly transported over Central
Europe and subsequently into the Central Mediterranean region. Figure 4 shows the volcanic aerosol mask for Cabauw, the Netherlands, for the period 17-20 May 2010. As for the Hamburg example, volcanic particles were observed over the entire altitude range covered by the instrument. The strongest feature is located at about $5 \mathrm{~km}$ a.s.l. around 18:00 UTC on 17 May, consistently with what was observed by the DLR and FAAM aircrafts (Turnbull et al., 2012; Newman et al., 2012). This layer slightly decreased in altitude in the following hours, down to $3.5 \mathrm{~km}$ a.s.l. around 20:00 UTC on 18 May. The layers reported as purple are aerosol layers of unknown type. The identification was not possible, because at these altitudes air masses arrived from the east after passing over Southern Europe and sometimes also Northern Africa. This complex transport scenario prevented a clear identification of the aerosol sources to date.

\section{Results: 4-D distribution of volcanic aerosol over Europe}

The methodology described in Sect. 3 was applied to all EARLINET data provided individually by each station with the required $1 \mathrm{~h}$ temporal averaging. In this way, information about the aerosol layering and types within the whole network was gathered. Geometrical properties of the volcanic cloud over Europe are presented with high resolution (typically $60-180 \mathrm{~m}$ ) in terms of the base and top of the volcanic layer. Once the top and the base of a layer are identified, the center of mass of the aerosol layer can be also estimated from lidar profiles. The center of mass gives us information about 


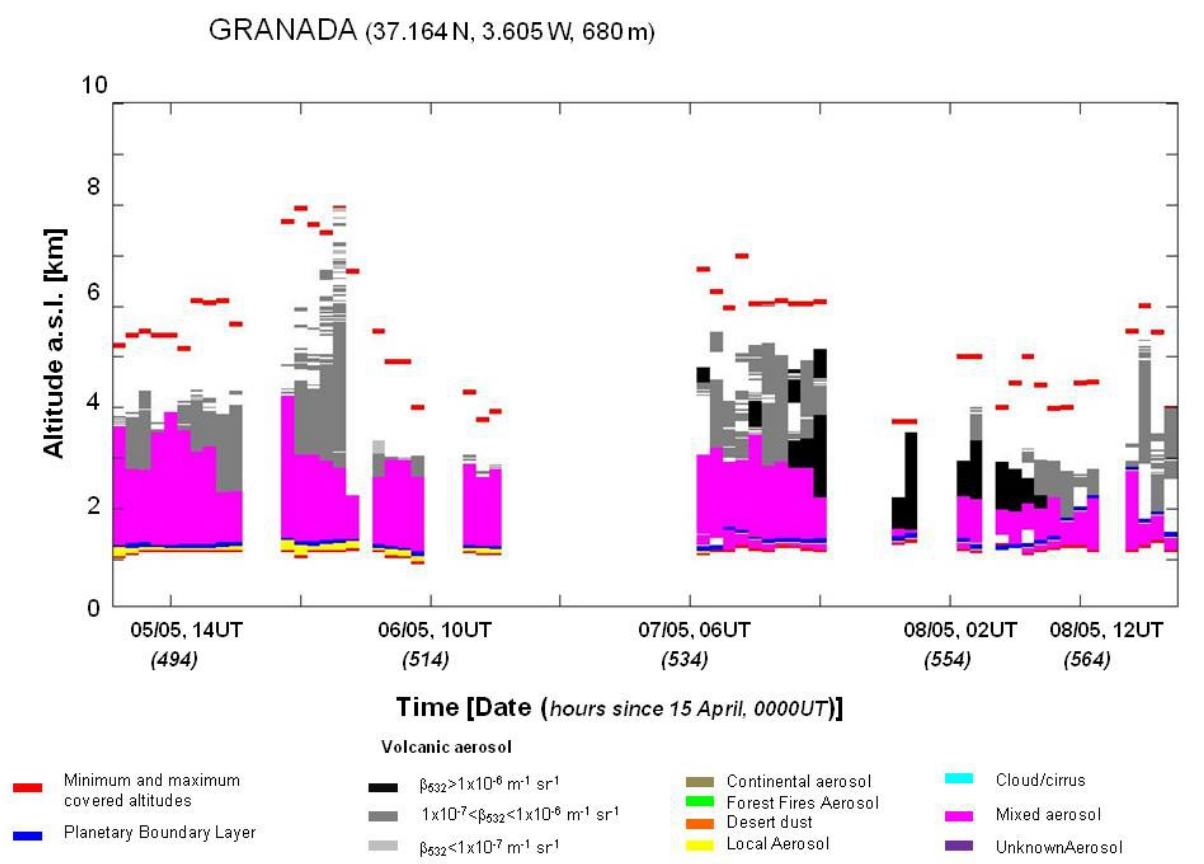

Fig. 3. Aerosol mask for the Granada EARLINET site in the 5-7 May 2010 period.

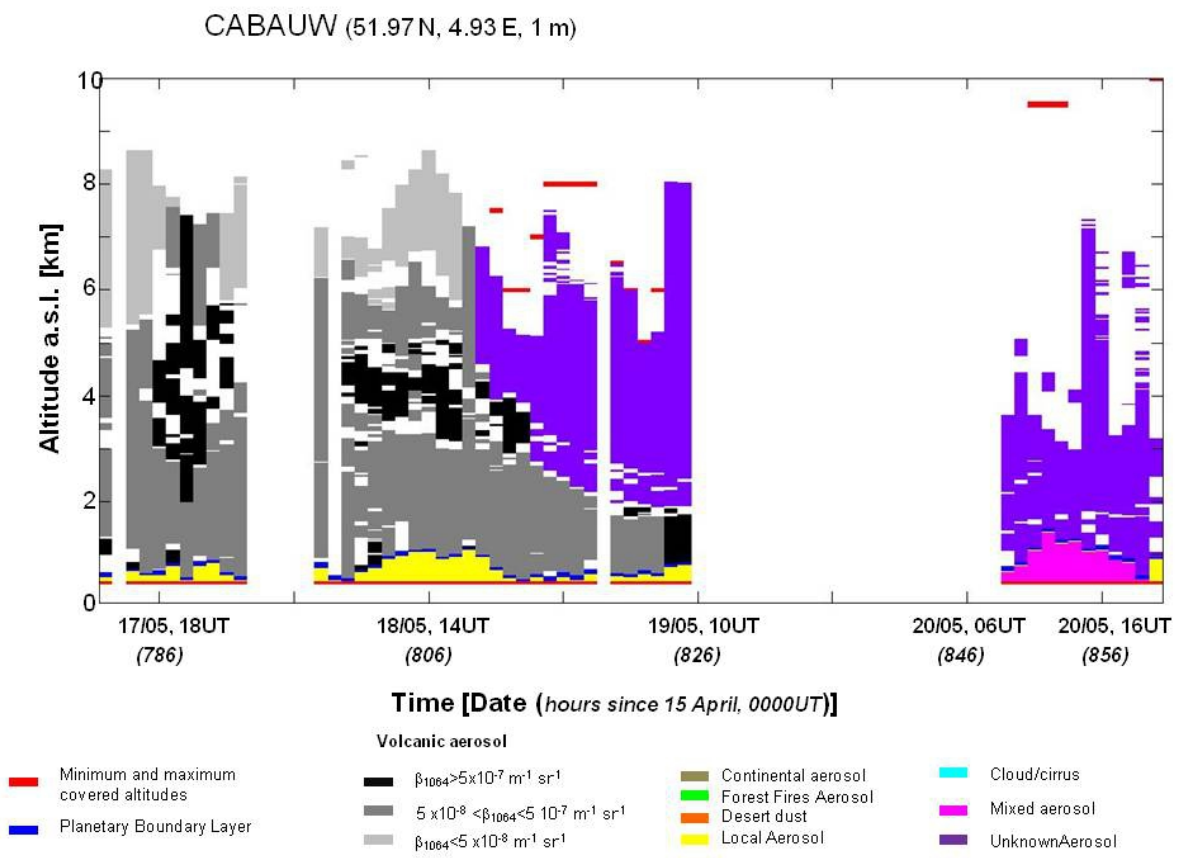

Fig. 4. Aerosol mask for the Cabauw EARLINET site in the 17-20 May 2010 period.

the altitude where the most relevant part of the aerosol load is located. In absence of wind, the temporal evolution of the center of mass of the aerosol layer could give insight about the dynamics of the whole layer. Assuming the microphysical properties to be homogenous within an aerosol layer, the center of mass can be estimated as the mean altitude of the identified layer weighted by the altitude-dependent aerosol backscatter coefficient (Mona et al., 2006). Due to the large number of performed measurements the arrival of volcanic cloud over Europe could be timed very accurately. Information about cases of mixing with other aerosol types and intrusions into the local PBL was gathered. 


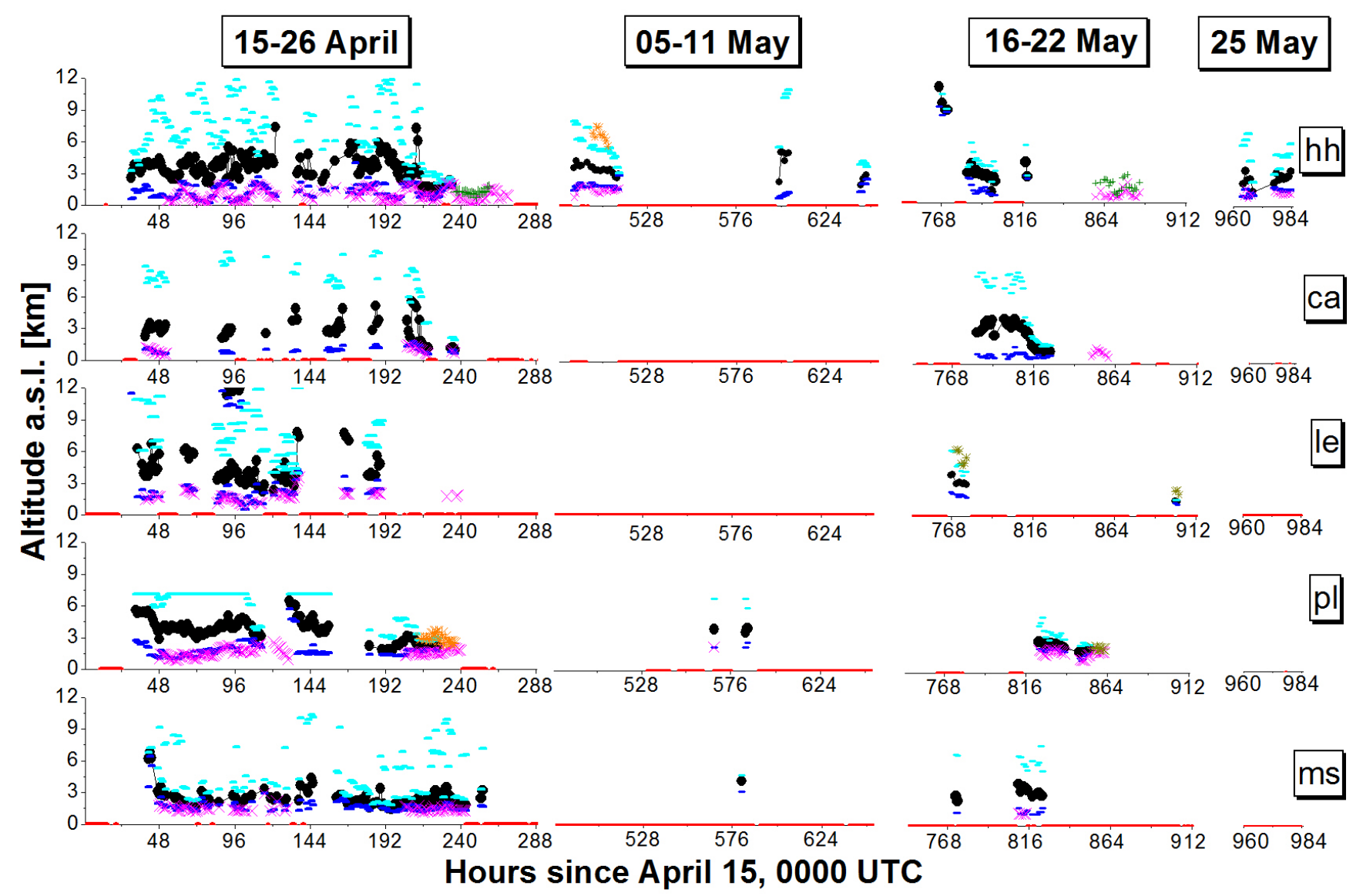

Fig. 5. Central Europe cluster: Hamburg (hh), Cabauw (ca), Leipzig (le), Palaiseau (pl) and Maisach (ms). The following quantities are reported hourly: center of mass of the identified volcanic layer (black dots), base and top of the identified volcanic layer (blue and cyan lines, respectively). Mixing with dust and continental aerosol is highlighted by orange and dark yellow symbols, respectively. Mixing with local aerosol above the PBL is reported in green. The intrusion in the PBL and, therefore, the mixing with local aerosol is indicated by a magenta cross located at the top of the PBL as obtained from lidar observations. Red line on the abscissa axes indicates no measurements.

Results are grouped into clusters representing five geographical regions: Central Europe - CE (Fig. 5), Central Mediterranean - CM (Fig. 6), Western Mediterranean - WM (Fig. 7), Eastern Mediterranean - EM (Fig. 8), and Eastern Europe - EE (Fig. 9). For each cluster, the temporal evolution of the volcanic layer is reported for each station for which a long record of data is available. Stations are listed in order of decreasing latitude, i.e. from North (top) to South (bottom) for each cluster. Further data from other stations (Andoya, Cork, Garmisch-Partenkirchen, Neuchatel, Payerne, Sofia, Barcelona, and Madrid) are not shown in the figures, but are available in the EARLINET database.

Starting from 15 April, 00:00 UTC, the following quantities are provided hourly: center of mass of the identified volcanic layer (multiple layers are regarded as a unique extended layer), base and top of the identified volcanic layer. These quantities are shown as black dots, blue lines, and cyan lines, respectively. Scenarios where a layer with volcanic aerosol mixed with another kind of aerosol are noted as well. For these cases the center of mass of the mixed layer is indicated. Mixes with dust and continental aerosol are highlighted by orange and dark yellow symbols, respectively. Mixing with local aerosol above the PBL is reported in green. The intrusion into the PBL and the subsequent mixing with local aerosol is indicated by magenta crosses located at the top of the PBL.

All cirrus clouds have been removed following the methodology described above, even though the presence of volcanic particles within the cirrus clouds cannot be ruled out and probably occurred regularly in the time period concerned. However, this aspect is outside the scope of the current publication and a devoted study related to cloud properties during the volcanic event would be required to address this issue. Some publications report specific cases (Seifert et al., 2011; Hoyle et al., 2011; Steinke et al., 2011; Bingemer et al., 2012; Rolf et al., 2012) but neither for all of Europe nor for the entire period of the eruption. 
Table 2. Geometrical and optical properties of the volcanic layers for each of the clusters: median value and minimum-maximum range value of base, top, center of mass $(\mathrm{CoM})$, integrated backscatter (IB) and backscatter $(\beta)$ at $532 \mathrm{~nm}$ are reported together with the maximum backscatter value (peak value) with corresponding altitude, location, and time.

\begin{tabular}{|c|c|c|c|c|c|c|c|c|}
\hline Cluster & $\begin{array}{l}\text { Base } \\
{[\mathrm{km}]}\end{array}$ & $\begin{array}{l}\text { Top } \\
{[\mathrm{km}]}\end{array}$ & $\begin{array}{l}\mathrm{CoM} \\
{[\mathrm{km}]}\end{array}$ & $\begin{array}{l}\text { IB } \\
{\left[1 \times 10^{-3}\right.} \\
\left.\mathrm{sr}^{-1}\right]\end{array}$ & $\begin{array}{l}\beta \\
{\left[1 \times 10^{-7}\right.} \\
\left.\mathrm{m}^{-1} \mathrm{sr}^{-1}\right]\end{array}$ & $\begin{array}{l}\text { Peak } \\
\text { Altitude } \\
{[\mathrm{km}]}\end{array}$ & $\begin{array}{l}\text { MaxBack } \\
{\left[\mathrm{m}^{-1} \mathrm{sr}^{-1}\right]}\end{array}$ & $\begin{array}{l}\text { MaxTime } \\
\text { [UTC] }\end{array}$ \\
\hline Central Europe & $\begin{array}{l}1.7 \\
0.2-11.7\end{array}$ & $\begin{array}{l}6.5 \\
1.6-14.5\end{array}$ & $\begin{array}{l}3.3 \\
1.0-13.0\end{array}$ & $\begin{array}{l}1.0315 \\
0.016-26\end{array}$ & $\begin{array}{l}3.6 \pm 2.6 \\
0.8-99.9\end{array}$ & 2.8 & $26.6 \times 10^{-6}$ & $\begin{array}{l}\text { 16 April } 2010- \\
05: 00(\mathrm{hh})\end{array}$ \\
\hline $\begin{array}{l}\text { Central } \\
\text { Mediterranean }\end{array}$ & $\begin{array}{l}2.0 \\
0.5-13.8\end{array}$ & $\begin{array}{l}5.2 \\
2.1-16.2\end{array}$ & $\begin{array}{l}3.1 \\
1.4-14.5\end{array}$ & $\begin{array}{l}1.18 \\
0.009-9.2\end{array}$ & $\begin{array}{l}5.8 \pm 3.9 \\
0.4-19.2\end{array}$ & 3.1 & $6.7 \times 10^{-6}$ & $\begin{array}{l}\text { 20 April } 2010- \\
08: 00 \text { (is) }\end{array}$ \\
\hline $\begin{array}{l}\text { Western } \\
\text { Mediterranean }\end{array}$ & $\begin{array}{l}2.5 \\
1.1-7.4\end{array}$ & $\begin{array}{l}6.2 \\
1.7-18.1\end{array}$ & $\begin{array}{l}4.1 \\
1.5-7.9\end{array}$ & $\begin{array}{l}0.6865 \\
0.003-6\end{array}$ & $\begin{array}{l}2.1 \pm 1.2 \\
0.2-42.2\end{array}$ & 3 & $17.9 \times 10^{-6}$ & $\begin{array}{l}13 \text { May } 2010- \\
06: 00 \text { (gr) }\end{array}$ \\
\hline $\begin{array}{l}\text { Eastern } \\
\text { Mediterranean }\end{array}$ & $\begin{array}{l}1.8 \\
1.0-6.4\end{array}$ & $\begin{array}{l}5.0 \\
1.7-12.2\end{array}$ & $\begin{array}{l}2.7 \\
1.5-7.7\end{array}$ & $\begin{array}{l}1.988 \\
0.02-10\end{array}$ & $\begin{array}{l}7.1 \pm 5.3 \\
0.6-23.4\end{array}$ & 1.3 & $5.02 \times 10^{-6}$ & $\begin{array}{l}22 \text { April } 2010- \\
17: 00 \text { (th) }\end{array}$ \\
\hline Eastern Europe & $\begin{array}{l}3.5 \\
1.2-8.2\end{array}$ & $\begin{array}{l}5.7 \\
2.9-13.4\end{array}$ & $\begin{array}{l}4.5 \\
2.8-8.2\end{array}$ & $\begin{array}{l}0.48 \\
0.3-2\end{array}$ & $\begin{array}{l}1.8 \pm 0.5 \\
0.8-3.4\end{array}$ & 2.3 & $1.35 \times 10^{-6}$ & $\begin{array}{l}\text { 17 April } 2010- \\
14: 00(\mathrm{mi})\end{array}$ \\
\hline
\end{tabular}

Finally, a red line is shown on the abscissa axes of the figures for hours when no measurements were performed. This situation typically arose during adverse weather conditions, but sometimes also because of technical problems. It should be noted that the network is not designed to be fully operational around the clock and that intensive measurement series lasting for more than one month imply a considerable effort for most of the stations.

Geometrical and optical properties of the volcanic layers are reported for each cluster in Table 2. Specifically, median values and minimum/maximum range values of base, top, center of mass, aerosol backscatter coefficient, and integrated backscatter at $532 \mathrm{~nm}$ are provided together with the maximum aerosol backscatter coefficient value (peak value) with corresponding altitude, location, and time. The aerosol backscatter coefficient at $532 \mathrm{~nm}$ has been chosen because it is available in each cluster.

During the first period (15-26 April) all stations within the Central Europe cluster (Hamburg (hh), Cabauw (ca), Leipzig (le), Palaiseau (pl), and Maisach (ms)) observed volcanic particles (see Fig. 5). Clouds were also very frequently observed. Low clouds over Cabauw often did not permit lidar data inversion. In the successive periods substantial cloud cover and rain limited the possibility to perform measurements, hence data had to be taken more sporadically. The center of mass of the volcanic layer was typically around 3$3.5 \mathrm{~km}$ for all stations apart from Maisach where it remained at about $2.5 \mathrm{~km}$. Intrusion into the PBL was a common feature for almost all observations. In the case of Maisach the volcanic layer came into contact with the boundary layer during the afternoon of 17 April. The process of mixing of the ash with locally produced aerosol was investigated with a very high temporal resolution of one hour (Groß et al., 2011). The state of mixing was determined from the particle lin- ear depolarization ratio applying a methodology proposed by Shimizu et al. (2004) and Tesche et al. (2009). Similar studies were also performed for three sites in Germany (Ansmann et al., 2011).

A peculiar feature was present over the Hamburg, Palaiseau, and Maisach stations during the first arrival of the volcanic cloud: a volcanic layer rapidly decreasing with altitude from 6 to ca. $3 \mathrm{~km}$ a.s.l. This phenomenon was associated with an air-mass propagation on the east side of an anti-cyclone, accompanied also by a stratospheric air intrusion documented by daily forecasts, similarly to those described by Stohl et al. (2003), Zanis et al. (2003) and Trickl et al. (2010). This behaviour became in some sense the signature of the Eyjafjallajökull plume as it was presented and discussed at many conferences and specific related events (e.g. Dacre et al., 2011). However, as emphasized in this publication, the presence of the volcanic plume was not always associated with this kind of time/altitude behaviour as many different scenarios were observed over Europe. The Hamburg, Palaiseau, and Maisach stations observed this apparent descending plume almost at the same altitude, but at different times. In Hamburg the apparent descent was observed from 05:00 to 17:00 UTC, 16 April (29 to $41 \mathrm{~h}$ since 15 April, 00:00 UTC), while in Palaiseau and Maisach it occurred between 16:00 UTC, 16 April, and 00:00 UTC, 17 April (40 to $48 \mathrm{~h}$ since 15 April, 00:00 UTC).

As shown in the mask in Fig. 1, the diurnal/nocturnal behaviour is evident in the Hamburg series for the layer top. For Hamburg the top of the PBL also exhibited a strong diurnal/nocturnal cycle, leading to the same behaviour for the center of mass of the volcanic layer as well. The seemingly constant layer top for Palaiseau was caused by fixing the maximum observation height at this station, hence the 


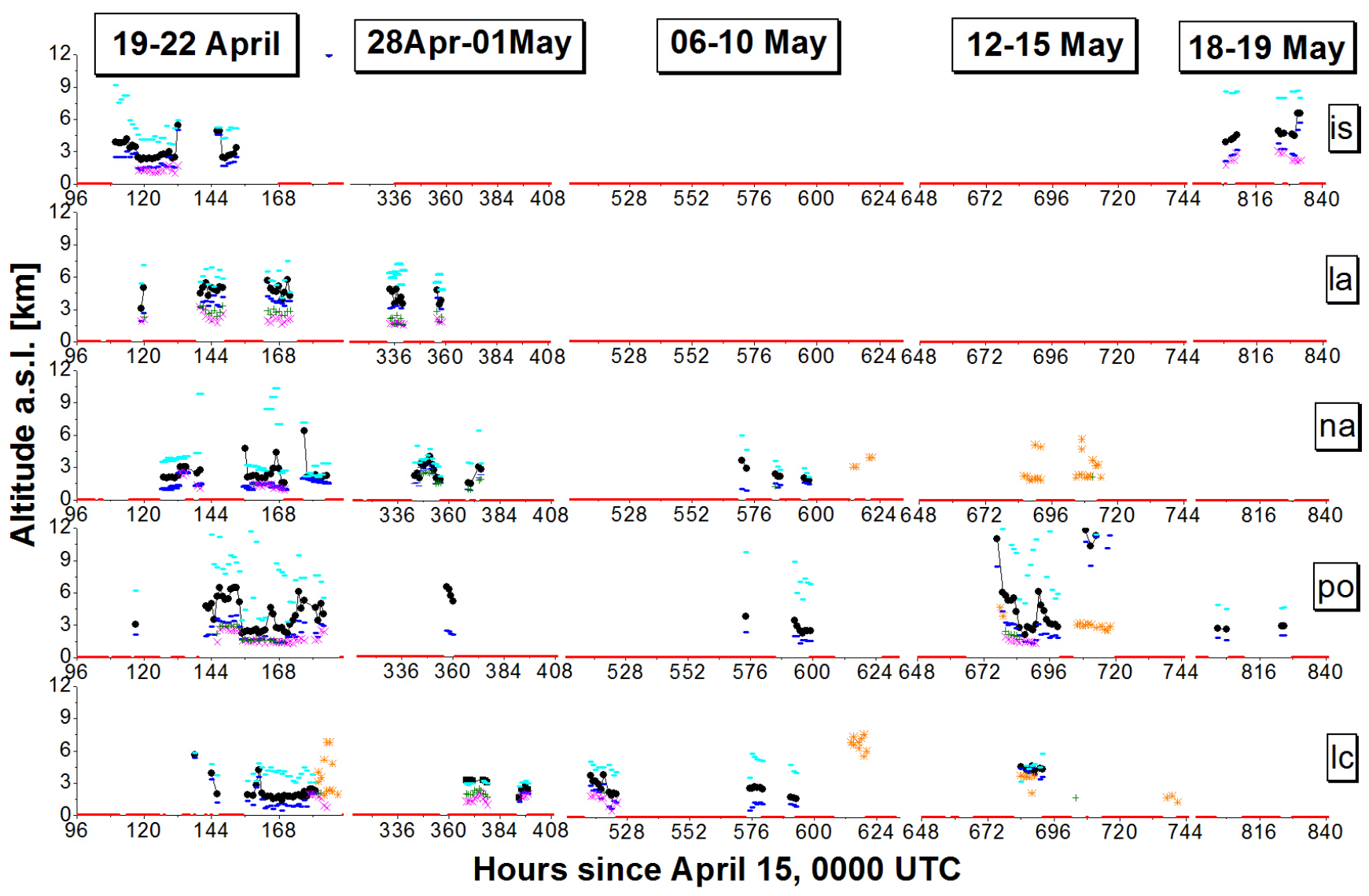

Fig. 6. As Fig. 5 for Central Mediterranean cluster: Ispra (is), L’Aquila (la), Naples (na), Potenza (po) and Lecce (lc).

presence of volcanic aerosol at higher altitudes cannot be excluded.

Within the Central Europe cluster typical volcanic layers were observed between 1.7 and $6.5 \mathrm{~km}$ height. Measured aerosol backscatter coefficients at $532 \mathrm{~nm}$ ranged from the minimum of $0.8 \times 10^{-7} \mathrm{~m}^{-1} \mathrm{sr}^{-1}$ to the maximum values of $26.6 \times 10^{-6} \mathrm{~m}^{-1} \mathrm{sr}^{-1}$ observed at an altitude of $2.8 \mathrm{~km}$ over Hamburg at 05:00 UTC on 16 April. The latter value represented the largest aerosol backscatter coefficient measured by EARLINET over Europe for the whole event. Extensive and intensive optical properties observed by the multiwavelength Raman lidar systems available in this region, together with sun photometer observations, allowed for the discrimination between sulfate particles and ash in the most intense volcanic layers (Ansmann et al., 2011).

The Central Mediterranean cluster Ispra (is), L'Aquila (la), Naples (na), Potenza (po), and Lecce (lc) (see Fig. 6) observed the volcanic cloud later in comparison to the Central Europe cluster. All the Italian stations observed the volcanic cloud in the period 19-22 April 2010 with the center of mass of the volcanic layer at lower altitudes (at about $2.8 \mathrm{~km}$ ) compared to the Central Europe cluster. During 610 May and 12-15 May, when there was air mass transport from the west, the volcanic cloud was observed only over the southern stations (na, po, and lc). In the period 18-19 May, the volcanic cloud was observed also in Northern Italy, over Ispra, in agreement with observations in the Central Europe cluster and over Maisach in particular.

An apparent descending layer between 10 and $5 \mathrm{~km}$ a.s.1. was observed over Potenza from 21 April, 02:00 UTC to 11:00 UTC (146 to $155 \mathrm{~h}$ since 15 April, 00:00 UTC). In the Central Mediterranean cluster, intrusion into the PBL was also observed very often. Mixing with Saharan dust also occurred during May for all southern stations.

In the Central Mediterranean cluster, the values of the aerosol backscatter coefficient were much lower compared to those measured over Central Europe. Here typical backscatter coefficient values at $532 \mathrm{~nm}$ were around $5.80 \times 10^{-7} \mathrm{~m}^{-1} \mathrm{sr}^{-1}$ with a maximum of $6.7 \times 10^{-6} \mathrm{~m}^{-1} \mathrm{sr}^{-1}$ observed over Ispra on 20 April, 08:00 UTC. Extensive and intensive optical properties measured in this cluster revealed the presence of mainly sulfate aerosols with the presence in few cases of some aged diluted ash (Mona et al., 2012; Perrone et al., 2012).

The Iberian Peninsula was affected by the volcanic cloud only for few days in May when the wind transported the 


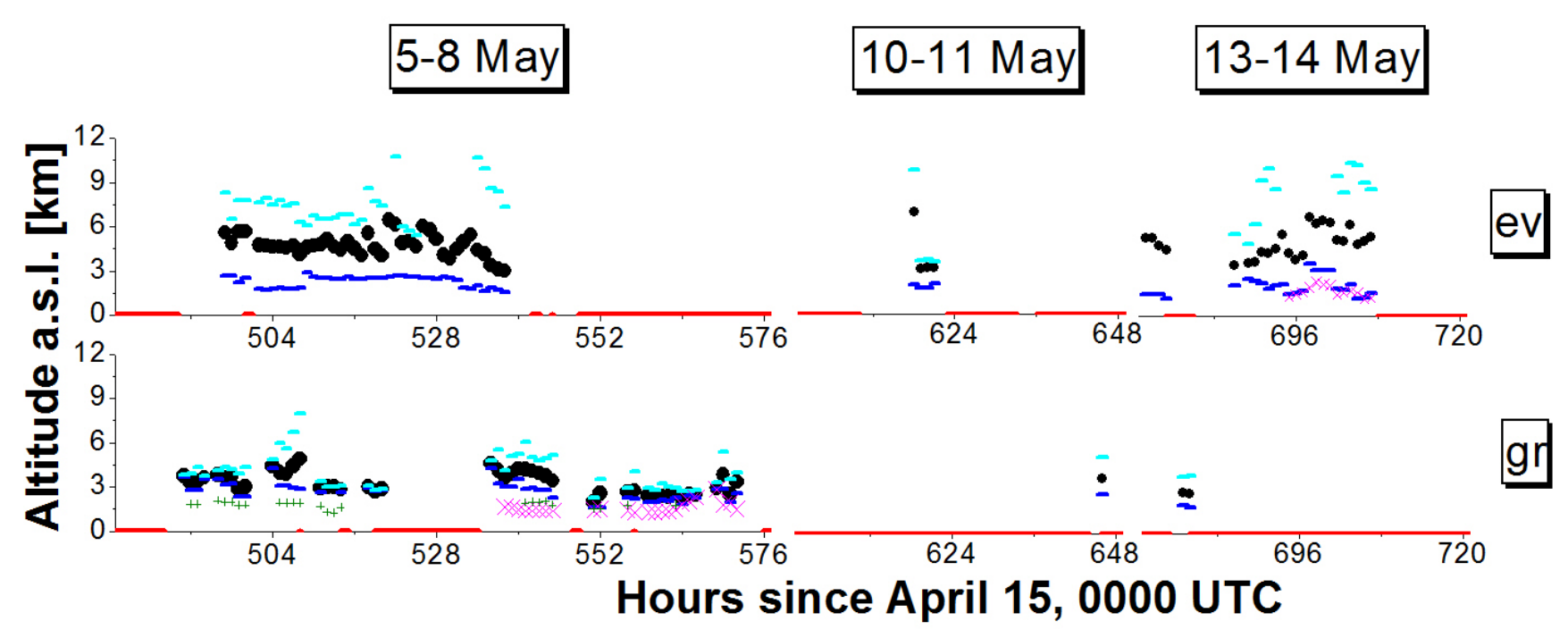

Fig. 7. As Fig. 5 for Western Mediterranean cluster: Evora (ev) and Granada (gr).

plume from Iceland towards the southwest. The weather was quite unstable, characterized by the presence of clouds and rain over the peninsula. Only few sporadic measurements were possible over Barcelona and Madrid and are therefore not reported here. More measurements were possible for more western stations: Evora (ev) and Granada (gr). The results are shown in Fig. 7. First observations of the volcanic cloud were made on 5 May, 10:00 UTC (490 h since 15 April, 00:00 UTC) over Granada. The typical altitude for the center of mass of the volcanic layer was about $4.1 \mathrm{~km}$. Similar patterns in the center of mass behaviour were observed at both stations on 6 May. There was, however, a time delay of about $8 \mathrm{~h}$ between Granada (535 to $544 \mathrm{~h}$ since 15 April, 00:00 UTC) and Evora (527 to $537 \mathrm{~h}$ since 15 April, 00:00 UTC). Data from Evora furthermore showed the center of mass to be approximately $300 \mathrm{~m}$ higher than over Granada.

Typical aerosol backscatter coefficient values at $532 \mathrm{~nm}$ were found to be for this cluster around $2.1 \times 10^{-7} \mathrm{~m}^{-1} \mathrm{sr}^{-1}$ with the maximum of $17.9 \times 10^{-6} \mathrm{~m}^{-1} \mathrm{sr}^{-1}$ observed over Granada at 06:00 UTC on 13 May. Multi-wavelength Raman lidar data from Granada were also used to retrieve microphysical properties during the night from 7 to 8 May. Particle effective radius ranged from $0.30 \pm 0.11 \mu \mathrm{m}$ to $0.55 \pm 0.13$ $\mu \mathrm{m}$ in the volcanic plume along this night. This study indicated that the volcanic plume over this station was mainly composed by sulfate and sulphuric acid droplets (NavasGuzmán et al., 2013).

In the Eastern Mediterranean cluster, Bucharest (bu), Thessaloniki (th), and Athens (at), generally less volcanic aerosol occurrences were recorded (see Fig. 8). The typical height of the center of mass of the volcanic layer has been observed at about $2.5 \mathrm{~km}$ over Athens and Thessaloniki and at a higher altitude (around $4.6 \mathrm{~km}$ ) over Bucharest. These values observed over Greece were lower in comparison to those observed over Central Europe and in good agreement with data from Southern Italy. An apparent layer descending from $7 \mathrm{~km}$ on 21 April, 22:00 UTC (165 h since 15 April, 00:00 UTC), down to $2.2 \mathrm{~km}$ on 22 April, 07:00 UTC (175 h since 15 April, 00:00 UTC), was observed over Athens. This observation was consistent with those from Potenza $20 \mathrm{~h}$ before. In the period 18-19 May, the center of mass of the volcanic layer was at an altitude of $2.5 \mathrm{~km}$, in agreement with the measurements at Potenza in the same period.

In this cluster, typical aerosol backscatter coefficient values at $532 \mathrm{~nm}$ were around $7.1 \times 10^{-7} \mathrm{~m}^{-1} \mathrm{sr}^{-1}$ with a maximum of $5.02 \times 10^{-6} \mathrm{~m}^{-1} \mathrm{sr}^{-1}$ found over Thessaloniki on 22 April, 17:00 UTC. Extensive and intensive aerosol optical properties and geometrical characteristics, combined with model simulations were used for aged ash and mineral dust aerosol discrimination over the Eastern Mediterranean area, in the height range between $2-5 \mathrm{~km}$ height a.s.l., especially during May 2010 (Papayannis et al., 2012).

The Eastern Europe cluster, Minsk (mi) and Belsk (be), observed the volcanic cloud mainly in the first period of the event (16-25 April, see Fig. 9) after the volcanic cloud had reached Central Europe and had spread out with parts of it moving in easterly direction. The volcanic layer observed in this cluster was characterized by a typical center of mass of $4.3 \mathrm{~km}$ over Belsk and $6.2 \mathrm{~km}$ over Minsk. Intrusion of the volcanic aerosol into the PBL was also commonly observed. Typical backscatter coefficient values at $532 \mathrm{~nm}$ observed over Minsk were around $1.8 \times 10^{-7} \mathrm{~m}^{-1} \mathrm{sr}^{-1}$ with a maximum of $1.35 \times 10^{-6} \mathrm{~m}^{-1} \mathrm{sr}^{-1}$ observed over Minsk at 14:00 UTC on 17 April.

Figure 10 provides an overview of the volcanic aerosol content as observed by EARLINET. Integrated backscatter at $532 \mathrm{~nm}$ is reported because the dataset of this optical property is the most abundant. For each cluster the mean 


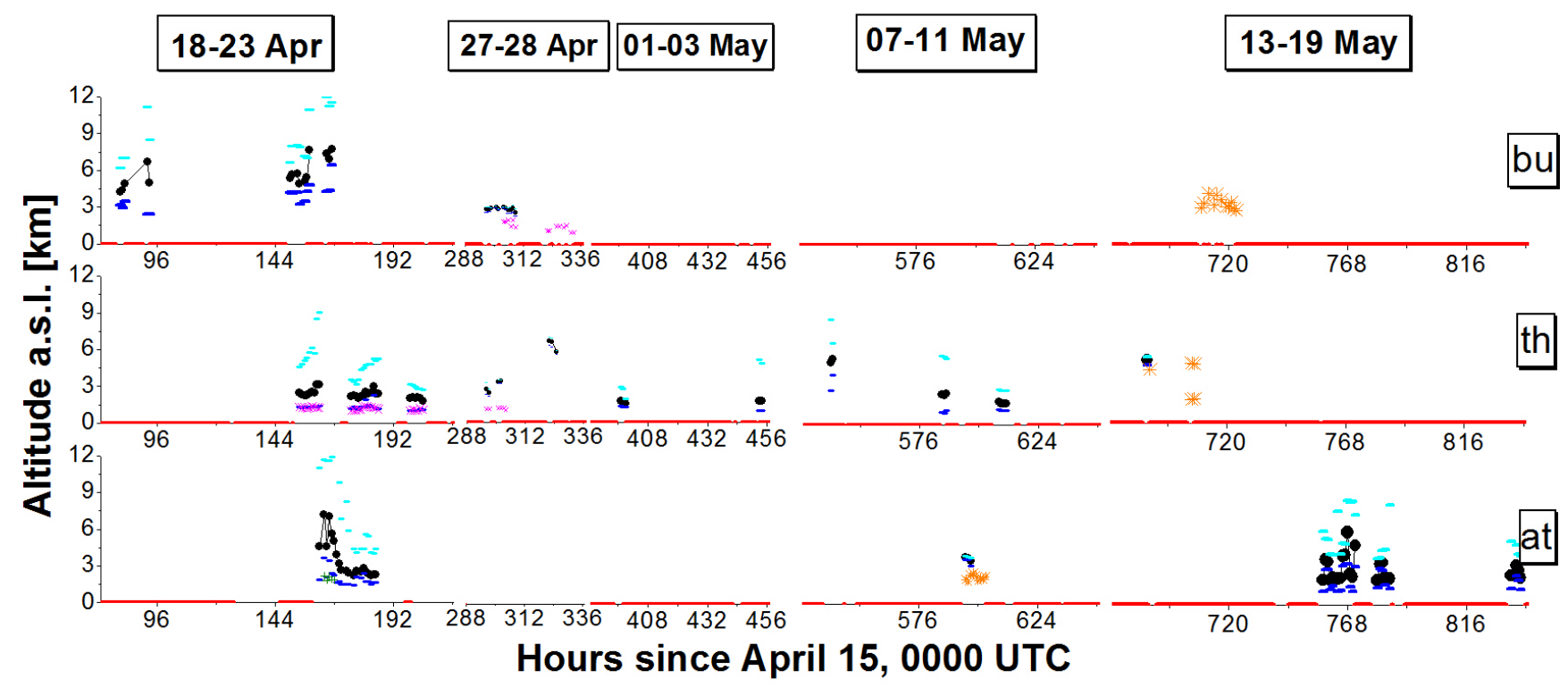

Fig. 8. As Fig. 5 for Eastern Mediterranean cluster: Bucharest (bu), Thessaloniki (th) and Athens (at).

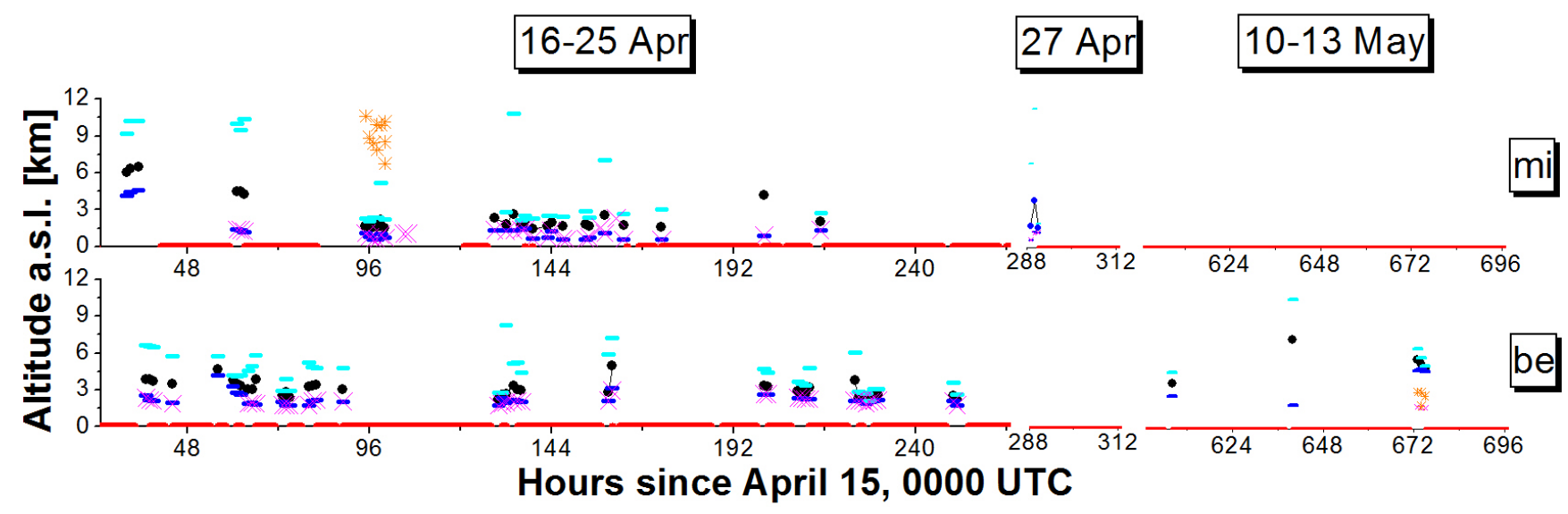

Fig. 9. As Fig. 5 for Eastern Europe cluster: Minsk (mi) and Belsk (be).

integrated backscatter evaluated inside the volcanic aerosol layer identified and discussed above and averaged inside the cluster is reported for each hour of observation. As a reference, the IB as measured at a representative site inside each cluster is reported too. Three main periods (15-26 April, 513 May and 17-20 May) are observed by the network and are characterized by: different vertical distributions (discussed above), different amounts of volcanic particles, specific horizontal path, and different modification and dispersion processes over Europe. During the first phase (15-26 April), the volcanic cloud moved from the $\mathrm{CE}$ cluster down to the $\mathrm{CM}$ and then to EM. An almost constant IB at $532 \mathrm{~nm}$ over the clusters (around $0.007 \mathrm{sr}^{-1}$ ) was observed in the first hours of the volcanic cloud observation. A sudden decrease in the IB values was found for all the 3 interested clusters down to $0.002 \mathrm{sr}^{-1}$ for $\mathrm{CE}$ and $0.001 \mathrm{sr}^{-1}$ for CM and EM. For the sake of completeness, it is important to remember here that just a few hourly data of high IB at $532 \mathrm{~nm}$ are measured over Hamburg in the early 16 April (see Table 2) which are out of the Fig. 10 scale. On the contrary, small IB values are observed over EE and there are no observations of the volcanic cloud over the WM.

During the second period, the volcanic aerosol content was instead around $0.005 \mathrm{sr}^{-1}$ over the WM and was considerably reduced in intensity during the transport over Europe toward CE, CM, EM and EE. The third interesting phase (17-20 May) was characterized by moderately high IB values (around $0.003 \mathrm{sr}^{-1}$ ) on CE, CM and EM clusters. In this case, the integrated backscatter over southern regions was occasionally higher than $\mathrm{CE}$ ones, probably because of aging processes of the particles. 
Table 3. Values for geometrical properties and optical properties (aerosol optical depth (AOD), lidar ratio $(S)$, linear particle depolarization ratio $(\delta)$, and Ångström exponent) observed from specific EARLINET multi-wavelength Raman lidar stations in specific periods of the Eyjafjallajökull eruption (April-May 2010). The table reports also the retrieved volcanic aerosol type with corresponding references.

\begin{tabular}{|c|c|c|c|c|c|c|c|c|c|c|}
\hline Date and hour & Location & $\begin{array}{l}\text { Height } \\
(\mathrm{km})\end{array}$ & $\mathrm{AOD}_{532}$ & $\begin{array}{l}S_{355} \\
(\mathrm{sr})\end{array}$ & $\begin{array}{l}S_{532} \\
(\mathrm{sr})\end{array}$ & $\delta 355$ & $\delta 532$ & Ångström $355 / 532$ & Type & Reference \\
\hline $\begin{array}{l}\text { 16 April } \\
\text { 2010, 14:15- } \\
\text { 15:30 UTC }\end{array}$ & Leipzig & $2.6-4.3$ & 0.35 & $60 \pm 5$ & $60 \pm 5$ & & $0.33 \pm 0.03$ & $0.03 \pm 0.40$ & ash & $\begin{array}{l}\text { Ansmann et } \\
\text { al. (2010) }\end{array}$ \\
\hline $\begin{array}{l}17 \text { April } \\
\text { 2010, 01:40- } \\
02: 30 \text { UTC }\end{array}$ & Munich & $2.6-3.5$ & & $50-60$ & $55 \pm 5$ & $0.35 \pm 0.02$ & $0.37 \pm 0.02$ & $-0.11 \pm 0.18$ & $\begin{array}{l}\text { Pure dry } \\
\text { ash }\end{array}$ & $\begin{array}{l}\text { Ansmann et } \\
\text { al. (2010) - Gross } \\
\text { et al. (2011) } \\
\text { Ansmann et } \\
\text { al. (2011) }\end{array}$ \\
\hline $\begin{array}{l}20 \text { April } \\
\text { 2010, 21:00- } \\
23: 05 \text { UTC }\end{array}$ & Potenza & $2.0-3.0$ & & $42 \pm 2$ & $50 \pm 3$ & & $0.15 \pm 0.03$ & $1.4 \pm 0.2$ & $\begin{array}{l}\text { Sulfates } \\
\text { with some } \\
\text { ash }\end{array}$ & Mona et al. (2012) \\
\hline $\begin{array}{l}7 \text { May } 2010 \text {, } \\
\text { 00:30-01:30 } \\
\text { UTC }\end{array}$ & Evora & $2.7-3.7$ & 0.07 & $39 \pm 10$ & $32 \pm 4$ & & & $0.68 \pm 0.63$ & $\begin{array}{l}\text { Fresh } \\
\text { volcanic } \\
\text { particles }\end{array}$ & Sicard et al. (2012) \\
\hline $\begin{array}{l}8 \text { May } 2010 \text {, } \\
\text { 03:30-04:30 } \\
\text { UTC }\end{array}$ & Granada & $2.6-2.9$ & & $47 \pm 7$ & $48 \pm 16$ & & $0.066 \pm 0.005$ & $0.79 \pm 0.54$ & $\begin{array}{l}\text { Sulfates } \\
\text { with some } \\
\text { ash }\end{array}$ & $\begin{array}{l}\text { Sicard et al. (2012) } \\
\text { Navas et al. (2013) }\end{array}$ \\
\hline $\begin{array}{l}\text { 13 May 2013, } \\
\text { 20:16- } \\
21: 01 \text { UTC }\end{array}$ & Potenza & $1.5-2.3$ & & $60 \pm 11$ & $78 \pm 12$ & & $0.16 \pm 0.07$ & $1.1 \pm 0.4$ & $\begin{array}{l}\text { Sulfates } \\
\text { with some } \\
\text { ash }\end{array}$ & Mona et al. (2012) \\
\hline $\begin{array}{l}\text { 17 May 2010, } \\
20: 15-20: 45 \\
\text { UTC }\end{array}$ & Cabauw & $2.7-6$ & 0.53 & $42 \pm 1$ & $44 \pm 24$ & & $0.30 \pm 0.03$ & $0.1 \pm 1.1$ & $\begin{array}{l}\text { Sulfate-ash } \\
\text { mixture }\end{array}$ & $\begin{array}{l}\text { Ansmann et } \\
\text { al. (2011) }\end{array}$ \\
\hline $\begin{array}{l}19 \text { May 2010, } \\
\text { 20:30-21:30 } \\
\text { UTC }\end{array}$ & Athens & $3.0-4.8$ & 0.05 & $67 \pm 13$ & $89 \pm 3$ & & & $0.57 \pm 0.26$ & $\begin{array}{l}\text { Aged } \\
\text { ash/sulfates }\end{array}$ & $\begin{array}{l}\text { Papayannis et } \\
\text { al. (2012) }\end{array}$ \\
\hline
\end{tabular}

All these results are in fair agreement with the volcanic cloud dispersion as forecast by EURAD (EURopean Air Pollution Dispersion) model: a complex dispersion of the volcanic cloud over a large part of Europe for the first days after 15 April (Fig. 11), the transport from Iceland to the Iberian peninsula and afterwards in the west-east direction for the first days of May (Fig. 12) and finally a well-defined transport along the north-west to south-east for the last part of the event (Fig. 13). Overlaying the EURAD forecast with maximum in IB as observed by EARLINET stations (Figs. 1113) allows for a better appreciation of the fair agreement between model and observations. The illustration is based on the EURAD forecast provided on the website daily during the event and is in reasonable agreement with other model results from FLEXPART (Stohl et al., 2011), VAAC, and COSMO-MUSCAT (Heinold et al., 2012). First of all we can conclude that the EARLINET network, even if not operative, covered the volcanic cloud dispersion in each identified phase, providing a detailed 4-D analysis of the event. In general there is good agreement in terms of timing of peak observations and in terms of aerosol amount: larger IB values are observed at stations interested for the first by the plume transport, afterwards a decrease in IB is observed moving far from the source. Differences are found in some cases in par- ticular for stations located at the boundary of the dispersion plume. This is probably related to differences in the time of reported model/observations, but could also be the effect of missing observations due to bad weather conditions and/or to EURAD model uncertainties at the boundary. A detailed and quantitative comparison between models and observations would require a devoted study with a strong contribution by the modelers. It is therefore beyond the scope of this paper and could be the object of further investigations.

For these and other studies, the database of EARLINET observations of volcanic cloud over Europe will be of great value. In particular, geometrical data for the layers related to the volcanic cloud have been collected and are publicly available on request in a relational database. More details about the Eyjafjallajökull 2010 EARLINET relational database can be found in the data user manual available on the EARLINET website. This database, specifically set up for this event, contains details about layers identified as volcanic (ash, sulfates, and modified volcanic particles) and mixed layers involving the presence of volcanic aerosol (e.g., volcanic-dust and volcanic-locally mixed layers). For each layer, base, top, and center of mass altitudes are reported together with aerosol backscatter mean and standard deviation values, integrated backscatter, and mean relative aerosol backscatter statistical 


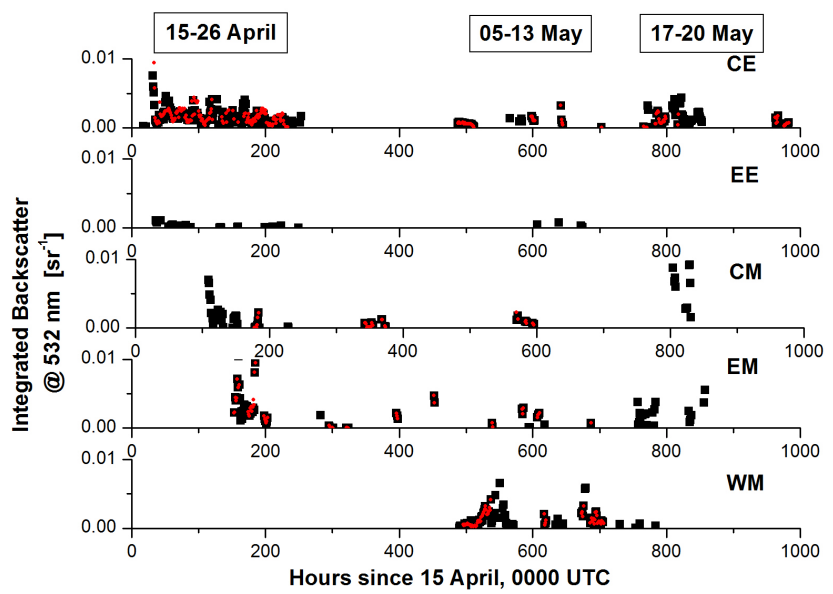

Fig. 10. Integrated Backscatter at $532 \mathrm{~nm}$ measured by EARLINET in the volcanic layers over the 5 clusters: Central Europe (CE), Eastern Europe (EE), Central Mediterranean (CM), Eastern Mediterranean (EM), and Western Mediterranean (WM). Mean values observed over the cluster are reported as black squares. Values measured at representative site for each cluster are reported as red dots: Hamburg, Belsk, Naples, Thessaloniki and Evora stations were selected as representative because of their large number of backscatter measurements at $532 \mathrm{~nm}$.

errors evaluated within the layer. Each layer is linked to the corresponding aerosol backscatter profile available in the EARLINET database. The following information is provided for each aerosol backscatter profile: station name and coordinates, time, minimum and maximum height investigated within each profile, first altitude above the fixed threshold in the relative error, PBL height, and the indication of whether there was an intrusion into the PBL. The name of the corresponding original file (netCDF) contained in the public EARLINET database (www.earlinet.org) is also reported for further exploitation. The Eyjafjallajökull 2010 EARLINET relational database is available on request through the related link on the EARLINET website.

Quantitative optical data, specifically aerosol backscatter and extinction coefficient profiles and particle linear depolarization ratio at different wavelengths, are available in the EARLINET database (www.earlinet.org) in the volcanic category. From these data, it is possible to derive lidar ratio (extinction-to-backscatter ratio) and Ångström exponent data. This kind of spectral extensive and intensive optical data are useful for aerosol typing and for the retrieval of microphysical properties (Müller et al., 1999; Veselovskii et al., 2002; Böckmann et al., 2005).

Table 3 summarizes the values for geometrical and optical properties (aerosol optical depth, lidar ratio, linear particle depolarization ratio, and Ångström exponent) observed from specific EARLINET multi-wavelength Raman lidar stations in specific periods of the event. The table also reports the re- trieved volcanic aerosol type together with the corresponding references.

In this publication, we report the results regarding the distribution of the volcanic cloud over Europe as directly observed by the EARLINET lidar network for the entire Eyjafjallajökull volcanic event (15 April-26 May 2010). The results presented in this publication comprise all valid EARLINET observations in the troposphere during the 2010 eruption event. The data also reveal the presence of volcanic aerosol at higher altitudes, reaching the upper tropospherelower stratosphere altitude range (UTLS) (Trickl et al., 2012). However, it was decided to focus only on the tropospheric region because the aerosol mask methodology presented in this work cannot be simply transferred to the UTLS region and above. The analysis of volcanic aerosol in the UTLS related to all observations available from the EARLINET stations able to provide stratospheric data require a separate study.

\section{Summary}

EARLINET made a very substantial effort to monitor the Eyjafjallajökull eruption event in April-May 2010 by performing almost continuous lidar measurements during the entire period. The coordinated observations by EARLINET and a methodology that was specifically designed ad hoc for this event provided a detailed description of the 4D distribution of the volcanic cloud over Europe for the whole event. Geometrical properties of the volcanic cloud over Europe were provided with high vertical resolution (typically 60-180 m) in terms of base, top, and center of mass of the volcanic layer.

A first volcanic layer was observed at an altitude of ca. $3 \mathrm{~km}$ and up to $6 \mathrm{~km}$ over Hamburg in the early morning of 16 April. In the following days the ash plume was observed over Central Europe (Germany and France) at 5-6 km a.s.l. and Belarus at $8 \mathrm{~km}$ a.s.l. The maximum backscatter value of $26.6 \times 10^{-6} \mathrm{~m}^{-1} \mathrm{sr}^{-1}$ was observed at an altitude of $2.8 \mathrm{~km}$ over Hamburg on 16 April. Volcanic particles were observed over Italy on 20 April and over Greece on 21 April. The volcanic cloud was persistent over Central Europe for the whole period (15-26 April), with varying aerosol loads. Apparent descending aerosol layers were typically observed in all of Europe and intrusion into the PBL was commonly detected at almost each site. In May volcanic particles were detected over Spain and Portugal and then over the Mediterranean and the Balkans. Volcanic particles were observed over Central Europe until 25 May.

Mixing of volcanic particles with other kind of aerosol (dust, continental and local) was identified. Mixing with Saharan dust was observed mainly during May for all southern stations.

The results about the 4-D distribution of the volcanic cloud are reported in a specific relational database available on request through the EARLINET website. 


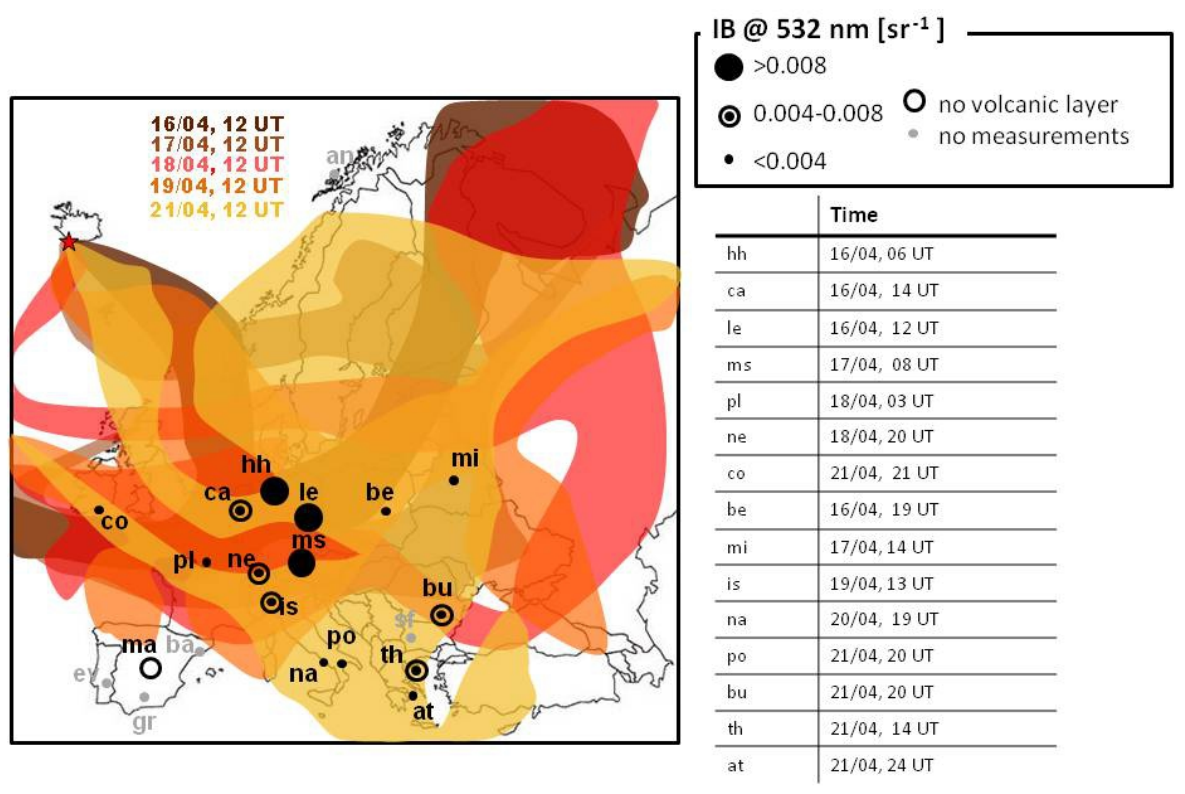

Fig. 11. Map of Europe showing the dispersion of the Eyjafjallajökull (red star) volcanic aerosol plume during the first week after the major eruption on 14 April 2010. The approximate location of the plume in the 3-5 km height range is given for 12:00 UT on 16 April (dark brown), 17 April (light brown), 18 April (red), 19 April (orange), and 21 April 2010 (yellow). The maximum integrated backscatter (IB) at 532 nm measured by each station is reported in black. The exact time location of the maximum IB reported is reported in the legend.

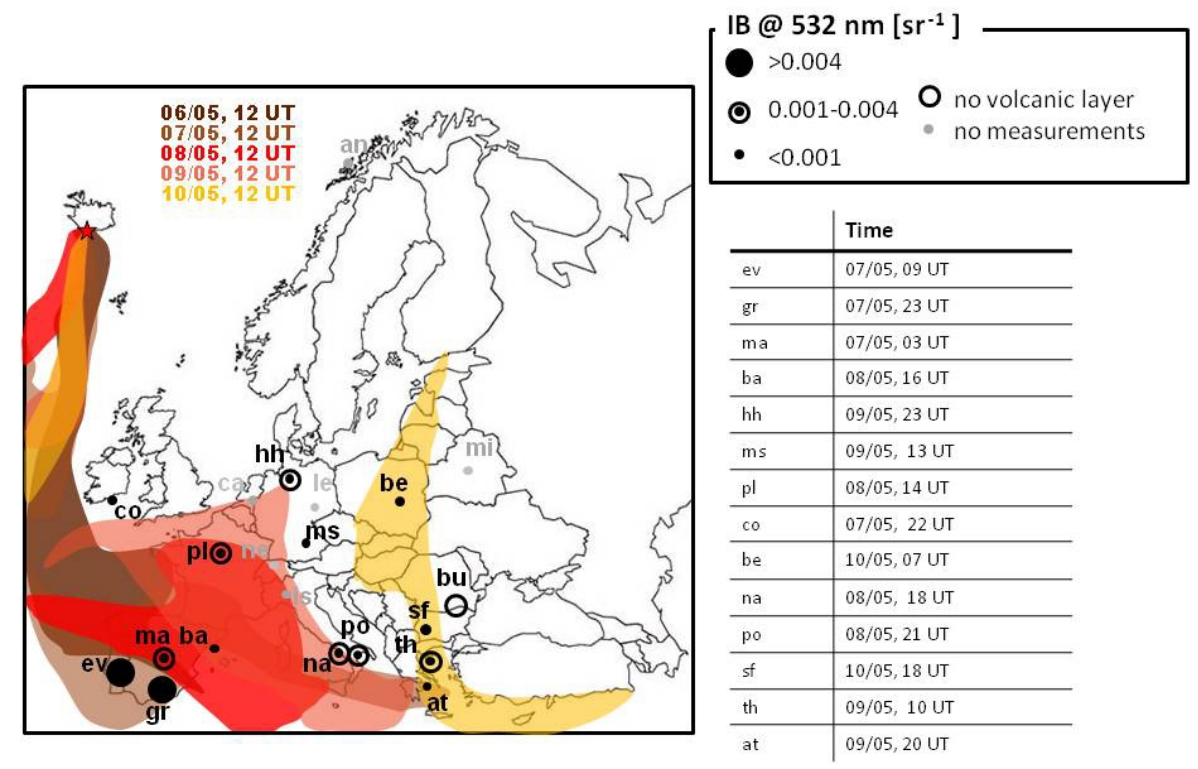

Fig. 12. Map of Europe showing the dispersion of the Eyjafjallajökull (red star) volcanic aerosol plume during the 6-10 May 2010 period. The approximate location of the plume in the 3-5 km height range is given for 12:00 UT on 6 May (dark brown), 7 May (light brown), 8 May (dark red), 9 May (light red), and 10 May 2010 (yellow). The maximum integrated backscatter (IB) at 532 nm measured by each station is reported in black. The exact time location of the maximum IB reported is reported in the legend.

Quantitative optical data, specifically aerosol backscatter and extinction coefficient profiles, linear depolarization ratio at different wavelengths, and derived lidar ratio and Ångström exponent profiles, are available through the EARLINET database (www.earlinet.org) in the volcanic category.
Typical optical data observed for this particular event have been also reported in this publication. EARLINET data collected for this event, including the specific relational database related to the geometrical properties of the volcanic cloud, 


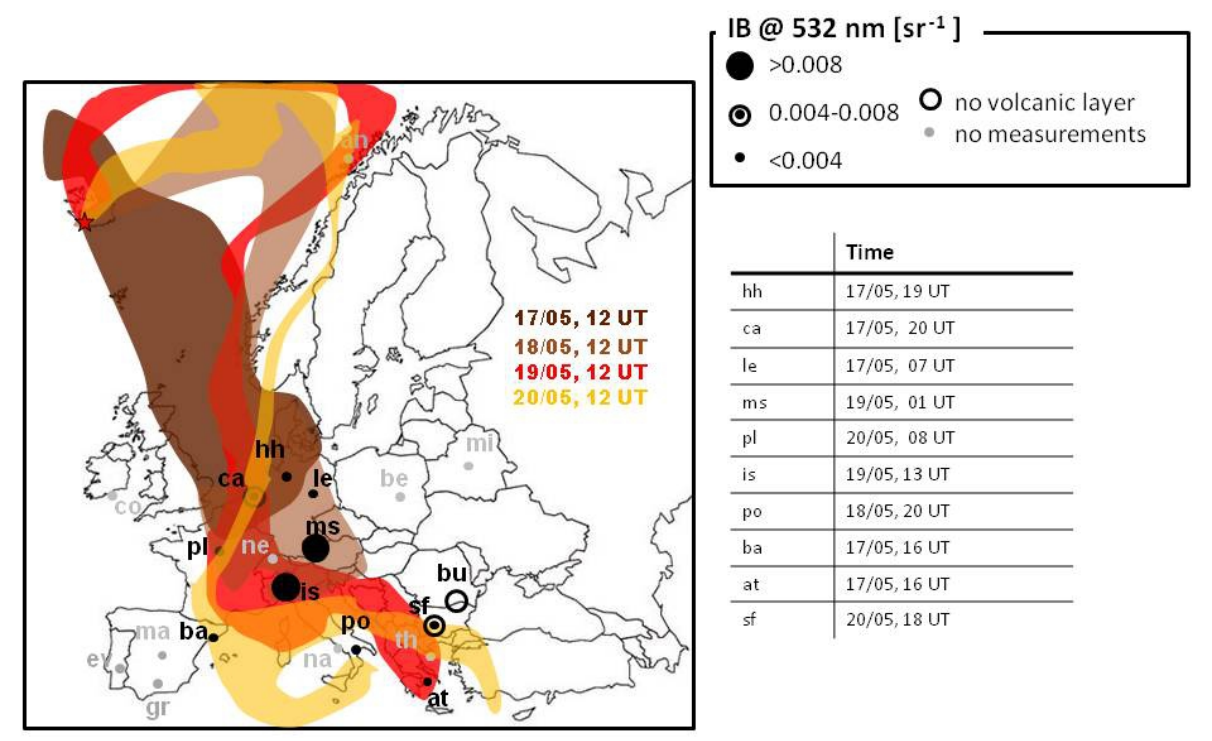

Fig. 13. Map of Europe showing the dispersion of the Eyjafjallajökull (red star) volcanic aerosol plume during the 6-10 May 2010 period. The approximate location of the plume in the 3-5 km height range is given for 12:00 UT on 17 May (dark brown), $18 \mathrm{May}$ (light brown), 19 May (red), and 20 May 2010 (yellow). The maximum integrated backscatter (IB) at $532 \mathrm{~nm}$ measured by each station is reported in black. The exact time location of the maximum IB reported is reported in the legend.

represent a unique database for model evaluation, data validation, and integration.

Acknowledgements. The financial support for EARLINET by the European Union under grant RICA 025991 in the Sixth Framework Programme is gratefully acknowledged. Since 2011 EARLINET has been integrated in the ACTRIS Research Infrastructure Project supported by the European Union Seventh Framework Programme (FP7/2007-2013) under grant agreement no. 262254.

The authors acknowledge the ESA financial support under the ESRIN contract 21769/08/I-OL and 22202/09/I-EC.

Additional financial support has been received from the Andalusia Regional Government through project P10-RNM-6299 and from the Spanish Ministry of Science and Technology through projects CGL2010-18782, and CSD2007-00067.

Authors would like to thank the NOAA Air Resources Laboratory (ARL) for the provision of the HYSPLIT backtrajectory analysis; the German Weather Service for the air mass backtrajectory analysis, NILU for providing FLEXTRA backtrajectories based on meteorological data provided from ECMWF (European Centre for Medium Range Weather Forecast) available at http://www.nilu.no/trajectories; and Tom L. Kucsera (GEST) at NASA/Goddard for back-trajectories available at the aeronet.gsfc.nasa.gov website. We also thank the Barcelona Supercomputing Center for forecasts with the Dust Regional Atmospheric Model (DREAM) and the Data User Element of the European Space Agency Data for data available from "ATSR World Fire Atlas". The Eyjafjallajökull volcanic activity was monitored through updated reports provided by the Iceland Meteorological Office and available at http://en.vedur.is/earthquakes-and-volcanism/articles/nr/2072.

Edited by: C. Bay Hasager

\section{References}

Amiridis, V., Balis, D. S., Giannakaki, E., Stohl, A., Kazadzis, S., Koukouli, M. E., and Zanis, P.: Optical characteristics of biomass burning aerosols over Southeastern Europe determined from UVRaman lidar measurements, Atmos. Chem. Phys., 9, 2431-2440, doi:10.5194/acp-9-2431-2009, 2009.

Ansmann, A., Bösenberg, J., Chaikovsky, A., Comerón, A., Eckhardt, S., Eixmann, R., Freudenthaler, V., Ginoux, P., Komguem, P., Linné, H., Ángel López Márquez, M., Matthias, V., Mattis, I., Mitev, V., Müller, D., Music, S., Nickovic, S., Pelon, J., Sauvage, L., Sobolewsky, P., Srivastava, M. K., Stohl, A., Torres, O., Vaughan, G., Wandinger, U., and Wiegner, M.: Longrange transport of Saharan dust to northern Europe: The 11-16 October 2001 outbreak with EARLINET, J. Geophys. Res., 108, 4783, doi:10.1029/2003JD003757, 2003.

Ansmann, A., Tesche, M., Groß, S., Freudenthaler, V., Seifert, P., Hiebsch, A., Schmidt, J., Wandinger, U., Mattis, I., Müller, D., Wiegner, M.: The 16 April 2010 major volcanic ash plume over central Europe: EARLINET lidar and AERONET photometer observations at Leipzig and Munich, Germany, Geophys. Res. Lett., 37, L13810 doi:10.1029/2010GL043809, 2010.

Ansmann, A., Tesche, M., Seifert, P. Groß, S.,Freudenthaler, V., Apituley, A., Wilson, K. M., Serikov, I., Linné, H., Heinold, B., Hiebsch, A., Schnell, F., Schmidt, J., Mattis, I., Wandinger, U., and Wiegner, M.: Ash and fine-mode particle mass profiles from EARLINET-AERONET observations over central Europe after the eruptions of the Eyjafjallajökull volcano in 2010, J. Geophys. Res., 116, D00U02, doi:10.1029/2010JD015567, 2011.

Arason, P., Petersen, G. N., and Bjornsson, H.: Observations of the altitude of the volcanic plume during the eruption of Eyjafjallajökull, April-May 2010, Earth Syst. Sci. Data, 3, 9-17, doi:10.5194/essd-3-9-2011, 2011. 
Bingemer, H., Klein, H., Ebert, M., Haunold, W., Bundke, U., Herrmann, T., Kandler, K., Müller-Ebert, D., Weinbruch, S., Judt, A., Wéber, A., Nillius, B., Ardon-Dryer, K., Levin, Z., and Curtius, J.: Atmospheric ice nuclei in the Eyjafjallajökull volcanic ash plume, Atmos. Chem. Phys., 12, 857-867, doi:10.5194/acp12-857-2012, 2012.

Böckmann, C., Wandinger, U., Ansmann, A., Bösenberg, J., Amiridis, V., Boselli, A., Delaval, A., De Tomasi, F., Frioud, M., Hågård, A., Horvat, M., Iarlori, M., Komguem, L., Kreipl, S., Larchevêque, G., Matthias, V., Papayannis, A., Pappalardo, G., Rocadembosch, F., Rodriguez, J. A., Schneider, J., Shcherbakov, V., and Wiegner, M.: Aerosol lidar intercomparison in the framework of the EARLINET project. 2. Aerosol backscatter algorithms, Appl. Opt. 43, 977-989 2004.

Böckmann, C., Mironova, I., Müller, D., Schneidenbach, L., and Nessler, R.: Microphysical aerosol parameters from multiwavelength lidar, J. Opt. Soc. Am. A, 22, 518-528, 2005.

Bösenberg, J., Ansmann, A., Baldasano, J. M., Balis, D., Böckmann, C., Calpini, B., Chaikovsky, A., Flamant, P., Hagard, A., Mitev, V., Papayannis, A., Pelon, J., Resendes, D., Schneider, J., Spinelli, N., Trickl, T., Vaughan, G., Visconti, G., and Wiegner, M.: EARLINET: A European Aerosol Research Lidar Network, in: Advances in Laser Remote Sensing, Eds: A. Dabas, C. Loth and J. Pelon, ISBN 2-7302-0798-8, 155-158, 2001.

Bukowiecki, N., Zieger, P., Weingartner, E., Jurányi, Z., Gysel, M., Neininger, B., Schneider, B., Hueglin, C., Ulrich, A., Wichser, A., Henne, S., Brunner, D., Kaegi, R., Schwikowski, M., Tobler, L., Wienhold, F. G., Engel, I., Buchmann, B., Peter, T., and Baltensperger, U.: Ground-based and airborne in-situ measurements of the Eyjafjallajökull volcanic aerosol plume in Switzerland in spring 2010, Atmos. Chem. Phys., 11, 10011-10030, doi:10.5194/acp-11-10011-2011, 2011.

Carnuth, W., Kempfer, U., and Trickl, T.: Highlights of the Tropospheric Lidar Studies at IFU within the TOR Project, Tellus B, 54, 163-185, 2002.

Chazette, P., Dabas, A., Sanak, J., Lardier, M., and Royer, P.: French airborne lidar measurements for Eyjafjallajökull ash plume survey, Atmos. Chem. Phys., 12, 7059-7072, doi:10.5194/acp-127059-2012, 2012.

Dacre, H. F., Grant, A. L. M., Hogan, R. J., Belcher, S. E., Thomson, D. J., Devenish, B. J., Marenco, F., Hort, M. C., Haywood, J. M., Ansmann, A., Mattis, I., and Clarisse, L.: Evaluating the structure and magnitude of the ash plume during the initial phase of the 2010 Eyjafjallajökull eruption using lidar observations and NAME simulations, J. Geophys. Res., 116, D00U03, doi:10.1029/2011JD015608, 2011.

Deshler, T.: A review of global stratospheric aerosol: Measurements, importance, life cycle, and local stratospheric aerosol, Atmos. Res., 90, 223-232, 2008.

Deshler, T., Anderson-Sprecher, R., Jäger, H., Barnes, J., Hofmann, D. J., Clemensha, B., Simonich, D., Grainger, R. G., and GodinBeekmann, S.: Trends in the non-volcanic component of stratospheric aerosol over the period 1971-2004, J. Geophys. Res., 111, D01201, doi:10.1029/2005JD006089, 2006.

Draxler, R. R. and Rolph, G. D.: HYSPLIT (HYbrid Single-Particle Lagrangian Integrated Trajectory) Model access via NOAA ARL READY Website (http://ready.arl.noaa.gov/HYSPLIT. php), NOAA Air Resources Laboratory, Silver Spring, MD, 2012.
Emeis, S., Forkel, R., Junkermann, W., Schäfer, K., Flentje, H., Gilge, S., Fricke, W., Wiegner, M., Freudenthaler, V., Groß, S., Ries, L., Meinhardt, F., Birmili, W., Münkel, C., Obleitner, F., and Suppan, P.: Measurement and simulation of the 16/17 April 2010 Eyjafjallajökull volcanic ash layer dispersion in the northern Alpine region, Atmos. Chem. Phys., 11, 2689-2701, doi:10.5194/acp-11-2689-2011, 2011.

Flentje, H., Claude, H., Elste, T., Gilge, S., Köhler, U., PlassDülmer, C., Steinbrecht, W., Thomas, W., Werner, A., and Fricke, W.: The Eyjafjallajökull eruption in April 2010 - detection of volcanic plume using in-situ measurements, ozone sondes and lidar-ceilometer profiles, Atmos. Chem. Phys., 10, 10085-10092, doi:10.5194/acp-10-10085-2010, 2010.

Freudenthaler, V., Groß, S., Engelmann, R., Mattis, I., Wandinger, U., Pappalardo, G., Amodeo, A., Giunta, A., D’Amico, G., Chaikovsky, A., Osipenko, F., Slesar, A., Nicolae, D., Belegante, L., Talianu, C., Serikov, I., Linne, H., Jansen, F., Wilson, K., de Graaf, M., Apituley, A., Trickl, T., Giehl, H., and Adam, M.: EARLI09 - Direct intercomparison of eleven EARLINET lidar, in: Proceedings of the 25th International Laser Radar Conference (ILRC), St. Petersburg, Russia, 5-9 July 2010, 891-902, 2010.

Gasteiger, J., Groß, S., Freudenthaler, V., and Wiegner, M.: Volcanic ash from Iceland over Munich: mass concentration retrieved from ground-based remote sensing measurements, Atmos. Chem. Phys., 11, 2209-2223, doi:10.5194/acp-11-22092011, 2011.

Groß, S., Freudenthaler, V., Wiegner, M., Gasteiger, J., Geiß, A., and Schnell, F.: Dual-wavelength linear depolarization ratio of volcanic aerosols: lidar measurements of the Eyjafjallajökull plume over Maisach, Germany, Atmos. Environ. 48, 85-96, doi:10.1016/j.atmosenv.2011.06.017, 2011.

Guerrero-Rascado, J. L., Olmo, F. J., Avilés-Rodríguez, I., NavasGuzmán, F., Pérez-Ramírez, D., Lyamani, H., and Alados Arboledas, L.: Extreme Saharan dust event over the southern Iberian Peninsula in september 2007: active and passive remote sensing from surface and satellite, Atmos. Chem. Phys., 9, 84538469, doi:10.5194/acp-9-8453-2009, 2009.

Hansen, J., Sato, M., Lacis, A., and Ruedy, R.: The missing climate forcing, Philos. Trans. R. Soc. B, 352, 231-240, 1997.

Heinold, B., Tegen, I., Wolke, R., Ansmann, A., Mattis, I., Minikin, A., Schumann, U., and Weinzierl, B.: Simulations of the 2010 Eyjafjallajökull volcanic ash dispersal over Europe using COSMO-MUSCAT, Atm. Environ., 48, 195-204, doi:10.1016/j.atmosenv.2011.05.021, 2012.

Hervo, M., Quennehen, B., Kristiansen, N. I., Boulon, J., Stohl, A., Fréville, P., Pichon, J.-M., Picard, D., Labazuy, P., Gouhier, M., Roger, J.-C., Colomb, A., Schwarzenboeck, A., and Sellegri, K.: Physical and optical properties of 2010 Eyjafjallajökull volcanic eruption aerosol: ground-based, Lidar and airborne measurements in France, Atmos. Chem. Phys., 12, 1721-1736, doi:10.5194/acp-12-1721-2012, 2012.

Hoyle, C. R., Pinti, V., Welti, A., Zobrist, B., Marcolli, C., Luo, B., Höskuldsson, Á., Mattsson, H. B., Stetzer, O., Thorsteinsson, T., Larsen, G., and Peter, T.: Ice nucleation properties of volcanic ash from Eyjafjallajökull, Atmos. Chem. Phys., 11, 9911-9926, doi:10.5194/acp-11-9911-2011, 2011.

Jäger, H.: Long-term record of lidar observations of the stratospheric aerosol layer at Garmisch-Partenkirchen, J. Geophys Res., 110, D08106, doi:10.1029/2004JD005506, 2005. 
Kravitz, B., Robock, A., Bourasa, A., Deshler, T., Wu, D., Mattis, I., Finger, F., Hoffmann, A., Ritter, C., Bitar, L., Duck, T., and Barnes, J. E.: Simulation and observations of stratospheric aerosols from the 2009 Sarychev volcanic eruption, J. Geophys. Res., 116, D18211, doi:10.1029/2010JD015501, 2011.

Langmann, B., Folch, A., Hensch, M., and Matthias, V.: Volcanic ash over Europe during the eruption of Eyjafjallajökull on Iceland, April-May 2010, Atmos. Environ., 48, 1-8, doi:10.1016/j.atmosenv.2011.03.054, 2012.

Mamouri, R. E., Papayannis, A., Amiridis, V., Müller, D., Kokkalis, P., Rapsomanikis, S., Karageorgos, E. T., Tsaknakis, G., Nenes, A., Kazadzis, S., and Remoundaki, E.: Multi-wavelength Raman lidar, sun photometric and aircraft measurements in combination with inversion models for the estimation of the aerosol optical and physico-chemical properties over Athens, Greece, Atmos. Meas. Tech., 5, 1793-1808, doi:10.5194/amt-5-1793-2012, 2012.

Marenco, F. and Hogan, R. J.:, Determining the contribution of volcanic ash and boundary layer aerosol in backscatter lidar returns: A three-component atmosphere approach, J. Geophys. Res., 116, D00U06, doi:10.1029/2010JD015415, 2011.

Marenco, F., Johnson, B., Turnbull, K., Newman, S., Haywood, J., Webster, H., and Ricketts, H.: Airborne lidar observations of the 2010 Eyjafjallajökull volcanic ash plume, J. Geophys. Res., 116, D00U05, doi:10.1029/2011JD016396, 2011.

Matthias V., Balis, D., Bösenberg, J., Eixmann, R., Iarlori, M., Komguem, L., Mattis, I., Papayannis, A., Pappalardo, G., Perrone, M. R., and Wang, X.: Vertical aerosol distribution over Europe: Statistical analysis of Raman lidar data from 10 European Aerosol Research Lidar Network (EARLINET) stations, J. Geophys. Res.-Atmos., 109, D18201, doi:10.1029/2004JD004638, 2004a.

Matthias, V., Böesenberg, J., Freudenthaler, V., Amodeo, A., Balis, D., Chaikovsky, A., Chourdakis, G., Comeron, A., Delaval, A., De Tomasi, F., Eximann, R., Hågård, A., Komguem, L., Kreipl, S., Matthey, R., Mattis, I., Rizi, V., Rodríguez, J. A., Simeonov, V., and Wang, X.: Aerosol lidar intercomparison in the framework of the EARLINET project. 1. Instruments, Appl. Opt., 43, 961-976, 2004b.

Matthias V., Aulinger, A., Bieser, J., Cuesta, J., Geyer, B., Langmann, B., Serikov, I., Mattis, I., Minikin, A., Mona, L., Quante, M., Schumann, U., and Weinzierl, B.: The ash dispersion over Europe during the Eyjafjallajökull eruption - comparison of CMAQ simulations to remote sensing and air-borne in-situ observations, Atmos. Environ., 48, 184-194, doi:10.1016/j.atmosenv.2011.06.077, 2012.

Mattis, I., Siefert, P., Müller, D., Tesche, M., Hiebsch, A., Kanitz, T., Schmidt, J., Finger, F., Wandinger, U., and Ansmann, A.: Volcanic aerosol layers observed with multiwavelength Raman lidar over central Europe in 2008-2009, J. Geophys. Res., 115, D00L04, doi:10.1029/2009JD013472, 2010.

Mona, L., Amodeo, A., Pandolfi, M., and Pappalardo, G.: Saharan dust intrusions in the Mediterranean area: Three years of Raman lidar measurements, J. Geophys. Res., 111, D16203, doi:10.1029/2005JD006569, 2006.

Mona, L., Amodeo, A., D'Amico, G., Giunta, A., Madonna, F., and Pappalardo, G.: Multi-wavelength Raman lidar observations of the Eyjafjallajökull volcanic cloud over Potenza, southern Italy, Atmos. Chem. Phys., 12, 2229-2244, doi:10.5194/acp-12-2229-
2012, 2012.

Müller, D., Wandinger, U., and Ansmann, A.: Microphysical particle parameters from extinction and backscatter lidar data by inversion with regularization: theory, Appl. Opt., 38, 2346-2357, 1999.

Müller, D., Mattis, I., Ansmann, A., Wandinger, U., Ritter, C., and Kaiser, D.: Multiwavelength Raman lidar observations of particle growth during long-range transport of forest-fire smoke in the free trosposphere, Geophys. Res. Lett., 34, L05803, doi:10.1029/2006GL027936, 2007.

Müller, D., Heinold, B., Tesche, M., Tegen, I., Althausen, D., Alados, Arboledas, L., Amiridis, V., Amodeo, A., Ansmann, A., Balis, D., Comeron, A., D’Amico, G., Gerasopoulos, E., Guerrero-Rascado, J. L., Freudenthaler, V., Giannakaki, E., Heese, B., Iarlori, M., Knippertz, P., Mamouri, R. E., Mona, L., Papayannis, A., Pappalardo, G., Perrone, R.-M., Pisani, G., Rizi, V., Sicard, M., Spinelli, N., Tafuro, A., and Wiegner, M.: EARLINET observations of the 14-22-May long-range dust transport event during SAMUM 2006: validation of results from dust transport modelling, Tellus, 61B, 325-339, 2009.

Navas-Guzmán, F., Müller, D., Bravo-Aranda, J. A., GuerreroRascado, J. L., Granados-Muñoz, M. J., Pérez-Ramírez, D., Olmo, F. J., and Alados-Arboledas, L.: Eruption of the Eyjafjallajökull Volcano in spring 2010: Multiwavelength Raman Lidar Measurements of Sulfate Particles in the Lower Troposphere, J. Geophys. Res., 118, 1804-1813, doi:10.1002/jgrd.50116, 2013.

Newman, S. M., Clarisse, L., Hurtmans, D., Marenco, F., Johnson, B., Turnbull, K., Havemann, S., Baran, A. J., O’Sullivan, D., and Haywood, J.: A case study of observations of volcanic ash from the Eyjafjallajökull eruption: 2. Airborne and satellite radiative measurements, J. Geophys. Res., 117, D00U13, doi:10.1029/2011JD016780, 2012.

Papayannis, A., Amiridis, V., Mona, L., Tsaknakis, G., Balis, D., Bösenberg, J., Chaikovski, A., De Tomasi, F., Grigorov, I., Mattis, I., Mitev, V., Müller, D., Nickovic, S., Pérez, C., Pietruczuk, A., Pisani, G., Ravetta, F., Rizi, V., Sicard, M., Trickl, T., Wiegner, M., Gerding, M., Mamouri, R. E., D’Amico, G., and Pappalardo, G.: Systematic lidar observations of Saharan dust over Europe in the frame of EARLINET (2000-2002), J. Geophys. Res., 113, D10204, doi:10.1029/2007JD009028, 2008.

Papayannis, A., Mamouri, R. E., Amiridis, V., Giannakaki, E., Veselovskii, I., Kokkalis, P., Tsaknakis, G., Balis, D., Kristiansen, N. I., Stohl, A., Korenskiy, M., Allakhverdiev, K., Huseyinoglu, M. F., and Baykara, T.: Optical properties and vertical extension of aged ash layers over the Eastern Mediterranean as observed by Raman lidars during the Eyjafjallajökull eruption in May 2010, Atmos. Environ., 48, 56-65, doi:10.1016/j.atmosenv.2011.08.037, 2012.

Pappalardo G., Amodeo, A., Mona, L., Pandolfi, M., Pergola, N., and Cuomo, V.: Raman lidar observations of aerosol emitted during the 2002 Etna eruption, Geophys. Res. Lett., 31, L05120, doi:10.1029/2003GL019073, 2004a.

Pappalardo G., Amodeo, A., Pandolfi, M., Wandinger, U., Ansmann, A., Bösenberg, J., Matthias, V., Amiridis, V., de Tomasi, F., Frioud, M., Iarlori, M., Komguem, L., Papayannis, A., Rocadenbosch, F., and Wang, X.: Aerosol lidar intercomparison in the framework of EARLINET. Part III. Raman lidar algorithm for aerosol extinction, backscatter and lidar ratio, Appl. Opt., 43, 5370-5385, 2004b. 
Pappalardo, G., Amodeo, A., Ansmann, A., Apituley, A., Alados Arboledas, L., Balis, D., Böckmann, C., Chaikovsky, A., Comeron, A., D’Amico, G., De Tomasi, F., Freudenthaler, V. Giannakaki, E., Giunta, A., Grigorov, I., Gustafsson, O., Groß, S., Haeffelin, M., Iarlori, M., Kinne, S., Linné, H., Madonna, F., Mamouri, R., Mattis, I., McAuliffe, M., Molero, F., Mona, L., Müller, D., Mitev, V. Nicolae, D., Papayannis, A., Perrone, M. R., Pietruczuk, A., Pujadas, M., Putaud, J.-P., Ravetta, F., Rizi, V., Serikov, I., Sicard, M., Simeonov, V., Spinelli, N., Stebel, K., Trickl, T., Wandinger, U., Wang, X., Wagner, F., and Wiegner, M.: EARLINET observations of the Eyjafjallajökull ash plume over Europe, in: Lidar Technologies, Techniques, and Measurements for Atmospheric Remote Sensing VI, edited by: Singh, U. N. and Pappalardo, G., Proc. of SPIE Vol. 7832, 78320J, 2010a.

Pappalardo, G., Wandinger, U., Mona, L., Hiebsch, A., Mattis, I., Amodeo, A., Ansmann, A., Seifert, P., Linne, H., Apituley, A., Alados Arboledas, L., Balis, D., Chaikovsky, A., D’Amico, G., De Tomasi, F., Freudenthaler, V., Giannakaki, E., Giunta, A., Grigorov, I., Iarlori, M., Madonna, F., Mamouri, R.-E., Nasti, L., Papayannis, A., Pietruczuk, A., Pujadas, M., Rizi, V., Rocadenbosch, F., Russo, F., Schnell, F., Spinelli, N., Wang, X., and Wiegner, M.: EARLINET correlative measurements for CALIPSO: First intercomparison results, J. Geophys. Res., 115, D00H19, doi:10.1029/2009JD012147, 2010b.

Perrone, M. R., De Tomasi, F., Stohl, A., and Kristiansen, N. I.: Integration of measurements and model simulations to characterize Eyjafjallajökull volcanic aerosols over south-eastern Italy, Atmos. Chem. Phys., 12, 10001-10013, doi:10.5194/acp-1210001-2012, 2012.

Pietruczuk, A., Krzyscin, J. W., Jaroslawski, J., Podgorski, J., Sobolewski, P., and Wink, J.: Eyjafjallajokull volcano ash observed over Belsk (52 degrees N, 21 degrees E), Poland, in April 2010, Int. J. Remote Sens., 31, 3981-3986, doi:10.1080/01431161.2010.498030, 2010.

Robock, A.: Volcanic eruptions and climate, Rev. Geophys., 38, 191-219, 2000.

Rolf, C., Krämer, M., Schiller, C., Hildebrandt, M., and Riese, M.: Lidar observation and model simulation of a volcanicash-induced cirrus cloud during the Eyjafjallajökull eruption, Atmos. Chem. Phys., 12, 10281-10294, doi:10.5194/acp-1210281-2012, 2012.

Rolph, G. D.: Real-time Environmental Applications and Display sYstem (READY) Website (http://ready.arl.noaa.gov), NOAA Air Resources Laboratory, Silver Spring, MD, 2012.

Sawamura, P., Vernier, J. P., Barnes, J. E., Berkoff, T. A., Welton, E. J., Alados-Arboledas, L., Navas-Guzmán, F., Pappalardo, G., Mona, L., Madonna, F., Lange, D., Sicard, M., Godin-Beekmann, S., Payen, G., Wang, Z., Hu, S., Tripathi, S. N., CordobaJabonero, C., and Hoff, R. M.: Stratospheric AOD after the 2011 eruption of Nabro volcano measured by lidars over the Northern Hemisphere, Environ. Res. Lett., 7, 034013, doi:10.1088/17489326/7/3/034013, 2012.

Schäfer, K., Thomas, W., Peters, A., Ries, L., Obleitner, F., Schnelle-Kreis, J., Birmili, W., Diemer, J., Fricke, W., Junkermann, W., Pitz, M., Emeis, S., Forkel, R., Suppan, P., Flentje, H., Gilge, S., Wichmann, H. E., Meinhardt, F., Zimmermann, R., Weinhold, K., Soentgen, J., Münkel, C., Freuer, C., and Cyrys, J.: Influences of the 2010 Eyjafjallajökull volcanic plume on air quality in the northern Alpine region, Atmos. Chem. Phys., 11,
8555-8575, doi:10.5194/acp-11-8555-2011, 2011.

Schoeberl, M. R. and Newman P. A.: A multiple-level trajectory analysis of vortex filaments, J. Geophys. Res., 100, 2580125816, 1995.

Schumann, U., Weinzierl, B., Reitebuch, O., Schlager, H., Minikin, A., Forster, C., Baumann, R., Sailer, T., Graf, K., Mannstein, H., Voigt, C., Rahm, S., Simmet, R., Scheibe, M., Lichtenstern, M., Stock, P., Rüba, H., Schäuble, D., Tafferner, A., Rautenhaus, M., Gerz, T., Ziereis, H., Krautstrunk, M., Mallaun, C., Gayet, J.F., Lieke, K., Kandler, K., Ebert, M., Weinbruch, S., Stohl, A., Gasteiger, J., Groß, S., Freudenthaler, V., Wiegner, M., Ansmann, A., Tesche, M., Olafsson, H., and Sturm, K.: Airborne observations of the Eyjafjalla volcano ash cloud over Europe during air space closure in April and May 2010, Atmos. Chem. Phys., 11, 2245-2279, doi:10.5194/acp-11-2245-2011, 2011.

Seifert, P., Ansmann, A., Groß, S., Freudenthaler, V., Heinold, B., Hiebsch, A., Mattis, I., Schmidt, J., Schnell, F., Tesche, M., Wandinger, U., and Wiegner, M.: Ice formation in ashinfluenced clouds after the eruption of the Eyjafjallajökull volcano in April 2010, J. Geophys. Res., 116, D00U04, doi:10.1029/2011JD015702, 2011.

Shimizu, A., Sugimoto, N., Matsui, I., Arao, K., Uno, I., Murayama, T., Kagawa, N., Aoki, K., Uchiyama, A., and Yamazaki, A.: Continuous observations of Asian dust and other aerosols by polarization lidars in China and Japan during ACE-Asia, J. Geophys. Res., 109, D19S17, doi:10.1029/2002JD003253, 2004.

Sicard, M., Guerrero-Rascado, J. L., Navas-Guzmán, F., Preißler, J., Molero, F., Tomás, S., Bravo-Aranda, J. A., Comerón, A., Rocadenbosch, F., Wagner, F., Pujadas, M., and Alados-Arboledas, L.: Monitoring of the Eyjafjallajökull volcanic aerosol plume over the Iberian Peninsula by means of four EARLINET lidar stations, Atmos. Chem. Phys., 12, 3115-3130, doi:10.5194/acp-12-31152012, 2012.

Solomon, S., Daniel, J. S., Neely III, R. R., Vernier, J.-P., Dutton, E. G., and Thomason, L. W.: The Persistently Variable "Background" Stratospheric Aerosol Layer and Global Climate Change, Science, 333, 866-870, 2011.

Steinke, I., Möhler, O., Kiselev, A., Niemand, M., Saathoff, H., Schnaiter, M., Skrotzki, J., Hoose, C., and Leisner, T.: Ice nucleation properties of fine ash particles from the Eyjafjallajökull eruption in April 2010, Atmos. Chem. Phys., 11, 12945-12958, doi:10.5194/acp-11-12945-2011, 2011.

Steyn, D., Baldi, G. M., and Hoff, R. M.: The Detection of Mixed Layer Depth and Entrainment Zone Thickness from Lidar Backscatter Profiles, J. Atm. Oceanic Tech., 16, 953-959, 1999.

Stohl, A.: Computation, accuracy and applications of trajectories a review and bibliography, Atmos. Environ., 32, 947-966, 1998.

Stohl, A., Wotawa G., Seibert P., and Kromp-Kolb H.: Interpolation errors in wind fields as a function of spatial and temporal resolution and their impact on different types of kinematic trajectories, J. Appl. Meteor., 34, 2149-2165, 1995.

Stohl, A., Bonasoni, P., Christofanelli, P., Collins, B., Feichter, J., Frank, A., Forster, C., Gerasopoulos, E., Gaggeler, H., James, P., Kentarchos, T., Kreipl, S., Land, C., Meloen, J., Papayannis, A., Priller, A., Seibert, P., Sprenger, M., Roelofs, G., Scheel, E., Schnabel, C., Siegmund, P., Tobler, L., Trickl, T., Wernli, H., Wirth, V., Zanis, P., and Zerefos, C.: Stratospheric-tropospheric exchange. A review and what we have learned from STACCATO, J. Geophys. Res., 108, D8516, doi:10.1029/2002JD002490, 
2003.

Stohl, A., Prata, A. J., Eckhardt, S., Clarisse, L., Durant, A., Henne, S., Kristiansen, N. I., Minikin, A., Schumann, U., Seibert, P., Stebel, K., Thomas, H. E., Thorsteinsson, T., Tørseth, K., and Weinzierl, B.: Determination of time- and height-resolved volcanic ash emissions and their use for quantitative ash dispersion modeling: the 2010 Eyjafjallajökull eruption, Atmos. Chem. Phys., 11, 4333-4351, doi:10.5194/acp-11-4333-2011, 2011.

Tesche, M., Ansmann, A., Müller, D., Althausen, D., Engelmann, R., Freudenthaler, V., and Groß, S.: Vertically resolved separation of dust and smoke over CapeVerde using multiwavelength Raman and polarization lidars during Saharan mineral dust experiment 2008, J. Geophys. Res., 114, D13202, doi:10.1029/2009JD011862, 2009.

Trickl, T., Feldmann, H., Kanter, H.-J., Scheel, H.-E., Sprenger, M., Stohl, A., and Wernli, H.: Forecasted deep stratospheric intrusions over Central Europe: case studies and climatologies, Atmos. Chem. Phys., 10, 499-524, doi:10.5194/acp-10-499-2010, 2010.

Trickl, T., Giehl, H., Jäger, H., and Vogelmann, H.: 35 years of stratospheric aerosol measurements at Garmisch-Partenkirchen: from Fuego to Eyjafjallajökull, and beyond, Atmos. Chem. Phys. Discuss., 12, 23135-23193, doi:10.5194/acpd-12-23135-2012, 2012.

Turnbull, K., Johnson, B., Marenco, F., Haywood, J., Minikin, A., Weinzierl, B., Schlager, H., Schumann, U., Leadbetter, S., and Woolley, A.: A case study of observations of volcanic ash from the Eyjafjallajökull eruption: 1. In situ airborne observations, J. Geophys. Res., 117, D00U12, doi:10.1029/2011JD016688, 2012.

Veselovskii, I., Kolgotin, A., Griaznov, V., Müller, D., Wandinger, U., and Whiteman, D. N.: Inversion with regularization for the retrieval of tropospheric aerosol parameters from multiwavelength lidar sounding, Appl. Opt., 41, 3685-3699, 2002.
Villani, M. G., Mona, L., Maurizi, A., Pappalardo, G., Tiesi, A., Pandolfi, M., D'Isidoro, M., Cuomo, V., and Tampieri, F.: Transport of volcanic aerosol in the troposphere: the case study of the 2002 Etna plume, J. Geophys. Res., 111, D21102, doi:10.1029/2006JD007126, 2006.

Wang, X., Boselli, A., D’Avino, L., Pisani, G., Spinelli, N., Amodeo, A., Chaikovsky, A. , Wiegner, M., Nickovic, S., Papayannis, A., Perrone, M.R., Rizi, V., Sauvage, L., and Stohl, A.: Volcanic dust characterization by EARLINET during Etna's eruptions in 2001-2002, Atmos. Environ., 42, 893-905, 2008.

Wiegner, M., Groß, S., Freudenthaler, V., Schnell, F., and Gasteiger, J.: The May/June 2008 Saharan Dust Event over Munich: Intensive Aerosol Parameters from Lidar Measurements, J. Geophys. Res., 116, D23213, doi:10.1029/2011JD016619, 2011.

Wiegner, M., Gasteiger, J., Groß, S., Schnell, F., Freudenthaler, V., and Forkel, R.: Characterization of the Eyjafjallajökull ashplume: Potential of lidar remote sensing, Phys. Chem. Earth, 4546, 79-86, doi:10.1016/j.pce.2011.01.006, 2012.

Winker, D. M., Liu, Z., Omar, A., Tackett, J., and Fairlie, D.: CALIOP observations of the transport of ash from the Eyjafjallajökull volcano in April 2010, J. Geophys. Res., 117, D00U15, doi:10.1029/2011JD016499, 2012.

Zanis, P., Trickl, T., Stohl, A., Wernli, H., Cooper, O., Zerefos, C., Gaeggeler, H., Schnabel, C., Tobler, L., Kubik, P. W., Priller, A., Scheel, H. E., Kanter, H. J., Cristofanelli, P., Forster, C., James, P., Gerasopoulos, E., Delcloo, A., Papayannis, A., and Claude, H.: Forecast, observation and modelling of a deep stratospheric intrusion event over Europe, Atmos. Chem. Phys., 3, 763-777, doi:10.5194/acp-3-763-2003, 2003. 